\title{
THE EMPIRICAL RELIABILITY OF MONETARY AGGREGATES AS INDICATORS: 1983-1987
}

\author{
MICHAEL R. DARBY, ANGELO R. MASCARO and MICHAEL L. MARLOW*
}

It is widely believed that monetary aggregates have failed to predict economic performance over 1983-87. This paper observes that the traditional definition of money (MI less other checkable deposits, or M1A) shows no evidence of structural change, and yields lower prediction errors for both real GNP and inflation over 1983-87Q2 than the errors obtained using MI or M2. If there is a mystery, it is not why MIA has done so well, but why economists abandoned it for MI or what was once called MIB (currency, demand deposits, and other checkable deposits).

....the definition of money is an issue to be decided not on grounds of principle as in the a priori approach, but on grounds of usefulness in organizing our knowledge of economic relationships. There is no hard and fast formula for deciding what total to call "money."

Friedman and Schwartz [1970, 104]

\section{INTRODUCTION}

It is widely believed that monetary aggregates have failed to predict real growth and inflation over 1983-87. This presumed breakdown of previously reliable linkages between money growth and future output and inflation has been variously attributed (by the present authors, among others) to changes in money demand induced by regulatory change and to parameter instability due to structural change. This paper observes that these disputations may be moot, since the traditional definition of money (currency plus demand deposits) shows no evidence of structural change, and yields nearly as low or lower prediction root mean square errors for both real GNP growth and inflation over 1983-87Q2 than the standard errors of estimate obtained for 1961-82. Part of the so-called "breakdown" in the monetary indicatorsespecially in the case of M1-may be explained by the fact that current M1 (or M1B) is defined much like the "old" M2, and current M1A is defined much like "old" M1. Thus, it is probably not too surprising that use of M1 as a monetary indicator does not yield consistent predictive power over a period of time in which it experienced redefinition. If there is a mystery in

* Under Secretary of Commerce for Economic Affairs; Principal Analyst, Congressional Budget Office; and Associate Professor, California Polytechnic State University, San Luis Obispo, CA. Much of this paper was written while the authors were at the U.S. Department of the Treasury. The views expressed in this paper are the personal views of the authors and not those of the U.S. Department of Commerce or the Congressional Budget Office. 
the 1980 s, it is not why M1A has done so well, but why economists abandoned it for broader M1B (currency, demand deposits and other checkable deposits or OCDs). ${ }^{1}$

With the nationwide introduction of negotiable order of withdrawal (NOW) accounts on January 1, 1981, M1A fell by 5.5 percent (a 22.1 percent per annum rate) in the first quarter, while M1B rose at a 3.1 percent per annum rate. At the time, the Federal Reserve System expected M1A demand to shift down as households chose to substitute from demand deposits to the newly available (in most states) OCDs. Accordingly, the sharp drop in M1A was expected to be reflected in a once-and-for-all upward shift in its velocity with no effect on nominal income or its components. ${ }^{2}$ However, consistent with the shock-absorber view of money demand, even if the long-run demand for M1A was unchanged, a sharp decrease in its quantity would induce an equal contemporaneous increase in its velocity. ${ }^{3}$ Contrary to the Federal Reserve's expectation, the shock absorber view would thus predict that the actual value of velocity would temporarily exceed its long-run equilibrium level so that nominal income would tend to fall or grow less rapidly as M1A velocity adjusted to the money shock.

Figure 1 shows that, compared to a relatively small drop in M1 velocity, the contemporaneous velocity of M1A moved sharply in the first quarter of $1981 .{ }^{4}$ The shock-absorber hypothesis suggests that contemporaneous velocity movements would be dominated by money supply shocks and thus attributes the different movements of M1A and M1 velocity to differences in magnitude and signs of the shocks in M1A and M1. What Milton Friedman [1983] calls "leading velocity" is a crude way of allowing nominal GNP to adjust to past money shocks. Panels $a$ and $b$ in Figure 2 illustrate leading velocity for lags between money and GNP of one and four quarters respectively. The longer the adjustment lag, the more leading velocity becomes a smooth, trend-dominated series for M1A. ${ }^{5}$ However, M1B continues to display a sizeable break from its historical pattern. This observation suggests that the recent behavior of the economy may be consistent with that indicated by movements in M1A, and that the choice to switch to M1B as the standard

1. Other authors have recently observed that M1A relationships have continued to perform well; e.g, see Paulus [1986] and Probyn and Booth [1986]. With the passage of time, it is easier to build a stronger case for their observation.

2. See "Monetary Policy Report to Congress" in Federal Reserve Bulletin, March 1981.

3. See Darby [1972] and Carr and Darby [1981] for the shock-absorber approach.

4. The money data displayed in Figures 1 and 2 are as reported by the Federal Reserve as opposed to our use of "adjusted" money data in the estimations as discussed at the bottom of Table I.

5. The issue of whether velocity is trend stationary or difference stationary has received much attention but is not examined here. See Rasche [1987] for a recent discussion and additional references. Christiano [1986] examines the issue of structural change in velocity within the context of the difference-stationary specification. 
FIGURE 1

Velocity (Logarithmic scale)

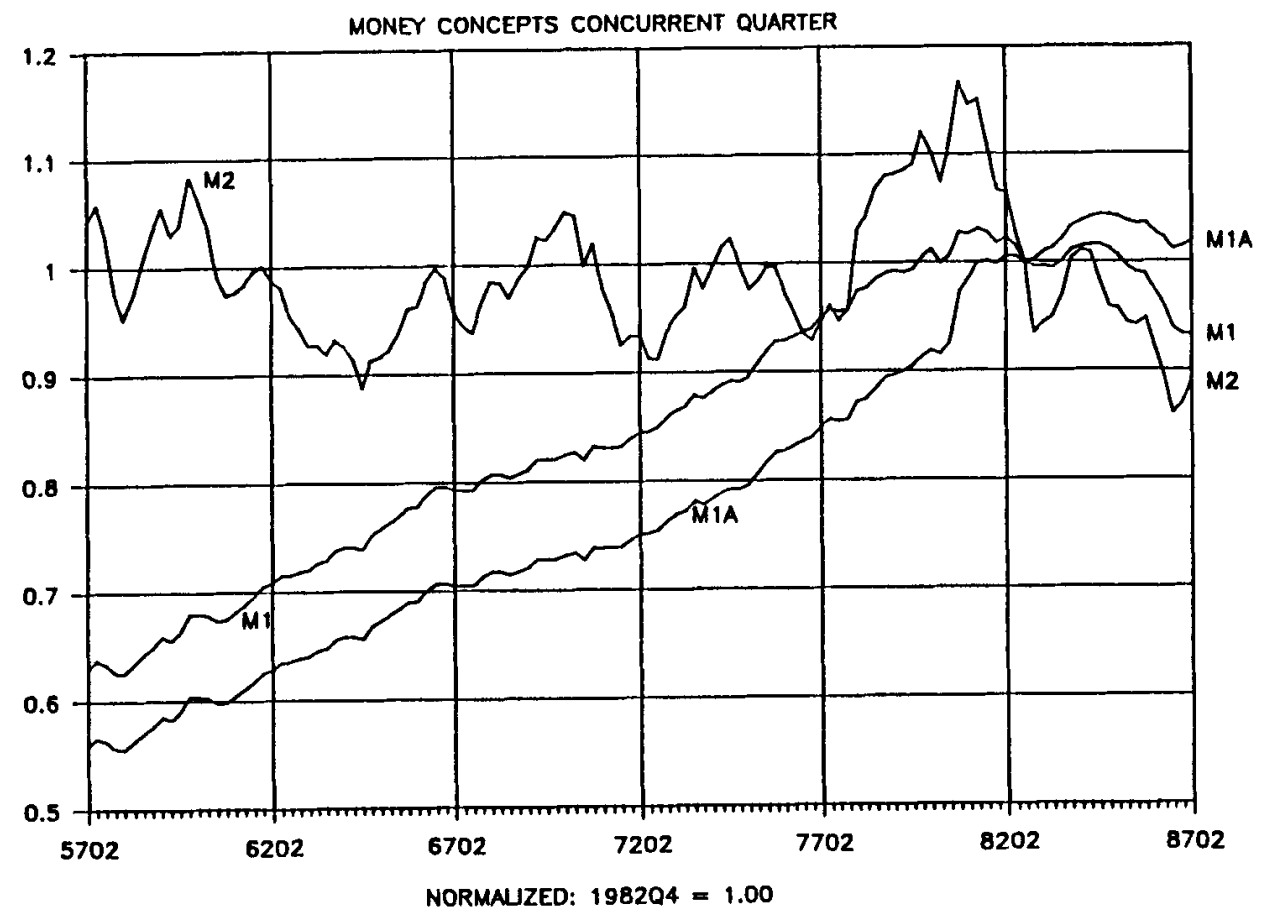




\section{FIGURE 2}

Pane1 a

VELOCITY [logarithmic scale] MONEY CONCEPTS LAGGED ONE GUARTER

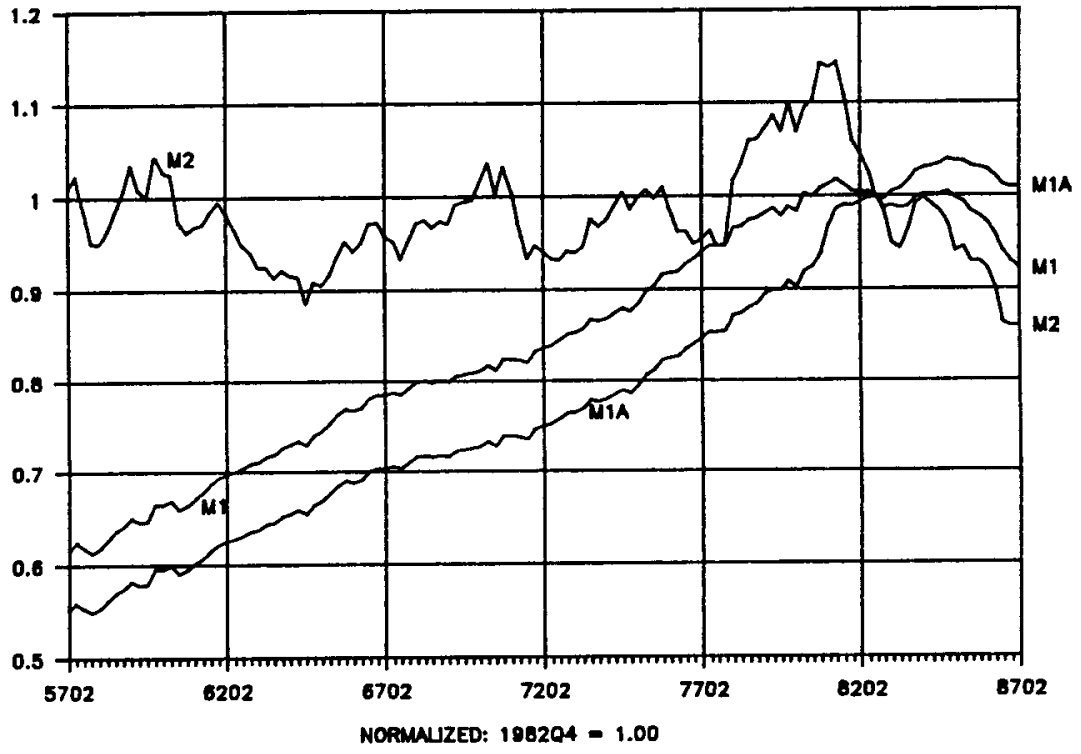

Panel b

VELOCITY [logarithmic scale]

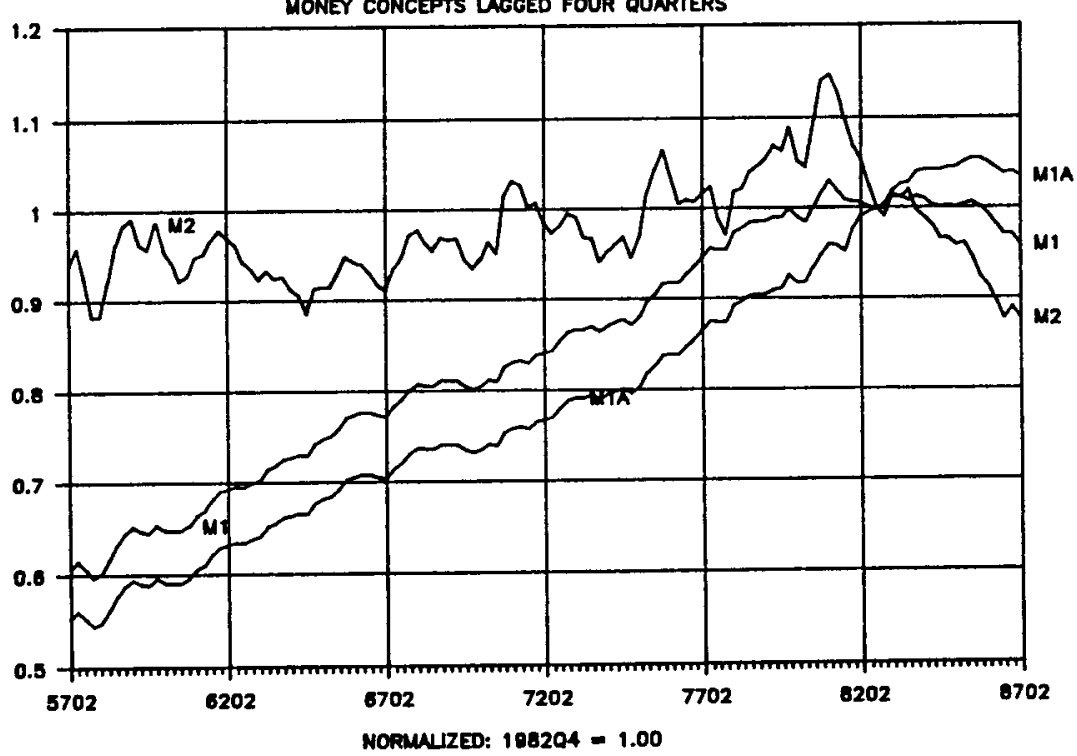


definition of the "narrow" money supply was unfortunate and a major source of recent forecasting failure. ${ }^{6}$

This paper runs a race among M1A, M1, and M2 by comparing out-ofsample forecasting performance and tests of structural stability. ${ }^{7}$ An explanation is also offered for the observed departure of M1 velocity from its historical trend. Based on a large battery of conventional tests, the results are remarkably favorable to the continued reliability of M1A as a useful indicator of future economic performance and for its relevance as a tool in monetary policy.

\section{INDICATOR PROPERTIES OF M1A, M1, M2}

The indicator properties of the monetary aggregates can be compared by examining their relative ability to mimic the movements in the quarterly growth of real GNP and the GNP deflator. This approach is based on the reduced-form framework of the St. Louis equation, first implemented by Andersen and Jordan [1968]. ${ }^{8}$ This approach was chosen for two reasons. First, it comes with a large body of published empirical research which contains information that can be used to deal with the econometric problem of model specification. Second, because the strengths and criticisms of the St. Louis equation are by now well known to the profession, attention can be concentrated on assessing the comparative indicator properties of the aggregates in the 1980s. Batten and Thornton [1986] review the criticisms of the St. Louis equation and provide references to the earlier debate.

\section{Methodology}

Distributed-lag equations are estimated for real growth and inflation over the trough-to-trough period 1961Q1-82Q4, successively using M1A, M1, and M2 in combination with cyclically adjusted federal government expenditures. Post-sample predictions over 1983Q1-87Q2 are then analyzed. Postsample prediction of eighteen quarters should reveal in an indirect but useful way any significant changes which have occurred in the underlying structural relationships between the alternative monetary aggregates, real GNP and prices. The equations are also used directly to test for structural change by comparing them with equations estimated over the full sample.

6. Friedman [1985] observes that current M1, or the old M1B, is more like the old M2.

7. The monetary base was also considered in work not reported here, but we concentrate on the standard M1 definition and the two alternatives (M1 A and M2) which do best empirically, in order to avoid confusion.

8. See Batten and Thornton [1983a] for a more recent version and additional references. Reduced forms such as those used throughout the paper are generally open to the observational equivalence criticism of Sargent and Wallace [1975]. Since such reduced forms are potentially consistent with a variety of structural mechanisms linking policy variables to output, prices, and market interest rates, they leave open the issue concerning diverse hypotheses about the effectiveness of short-term stabilization policy. 
The departure from the original St. Louis approach of focusing on nominal GNP growth is not novel since others have estimated the effects of money separately on real output growth and inflation. For earlier examples, see Barro [1978; 1981], Barro and Rush [1980], Burger [1978], Carlson [1980], Karnosky [1976], and Friedman and Schwartz [1982]. The main advantage of the disaggregated approach is that it discloses information on whether changes in the indicator properties of the monetary aggregates are related more to inflation (and indirectly interest rates) or to real output. The former could suggest that financial innovation played a role in the recent observed relation between money and the economy. If so, then any change should not be permanent since financial innovation has occurred throughout history, and Friedman and Schwartz [1982] find evidence of a stable relation between money and prices over nearly a century of data for the U.S. and the U.K. The latter could be indicative of a more permanent change.

Information from previous studies helps determine the specification of the distributed lags for the monetary aggregates. Barro's [1982] analysis using annual data suggests that the impact of money growth on real economic growth lasts about three years. Initially positive, the effects turn negative, with a pattern suggestive of a second-degree polynomial. For the inflation equation, Carlson [1980] found that the distributed-lag pattern shifted after 1969. Prior to 1969 , the full effects of money on prices took five years, versus three years in the 1970s. Since the sample period extends over both periods examined by Carlson, an intermediate span of four years is assumed to be an acceptable approximation of lag length. In addition, the pattern obtained by averaging the coefficients in the two subsamples used by Carlson turns out to be representable by a second-degree polynomial. Because of a lack of success in obtaining similar information to specify the distributed-lag pattern for federal expenditures, identical restrictions were imposed for both monetary and fiscal variables in any given equation.

Andersen and Jordan [1968] and Jordan [1986] stress the importance, and perhaps dominance, of influences besides monetary and fiscal policy on nominal GNP. The relative price of imported oil, measured by the Venezuelan price of petroleum relative to the GNP deflator, was included here to account for one of these factors. ${ }^{9}$ The growth rate of this variable appears in the inflation equation with the same distributed-lag specification as monetary and fiscal variables. In the real growth equation, the squared growth rate is used (a departure from the Rasche and Tatom [1977] specification), rather than simply the growth of the relative oil price measure. The framework of those authors involves estimating an aggregate production function with en-

9. Major periods of relative price change occurred as a result of OPEC actions in 1973-74, 1979-80 and 1986. Sharp changes in relative domestic prices also occurred in January 1981 as a result of decontrol. 
ergy as a separate factor, so that changes in relative energy prices exert symmetrical effects on aggregate output. Since the U.S. is a net importer of oil, this may characterize the ultimate relation between relative oil prices and aggregate output. But the short-run effects of changes in relative prices can be quite different. As discussed in Mayer [1974], impediments to the immediate reallocation of factors can force the economy to move inside its long-run production frontier and temporarily operate along a short-run frontier, possibly at a temporarily depressed level of measured overall activity. Eventually, in response to the signal from changed relative prices, resources are reallocated, and the economy resumes growth along a new expansion path. With quarterly data, use of the squared change in the logarithm of relative oil prices (expressed as a percentage) is one way to capture this effect, and squaring has the additional advantage of weighing relatively large changes more heavily than small ones. Mork [1987] provides evidence of asymmetric reactions following the 1986 oil price decline.

Dummy variables control for credit controls in 1980Q2 and (from Darby [1982]) for the effects on measured real GNP and prices of implementation and removal of price controls over 1971Q3-74Q4. Money growth is adjusted for the impact effects of deregulation, as described in Table I.

Indicator equations. Table I summarizes the results of econometric equations applied over 1961Q1-82Q4 to the quarterly growth of real GNP and the GNP deflator respectively, alternatively using M1A, M1, and M2. The oil-shock variable is included in the real GNP equations, while the relative oil price is included in the GNP deflator equations. Equations which exclude the oil variables are not exhibited here. Darby, Mascaro and Marlow [1987] present both equations and argue that the results (with and without the oil variables) do not substantially differ from one another. For the polynomial distributedlag (PDL) variables, two statistics are reported: the $t$-statistic on the sum of estimated coefficients and the F-statistic significance level on the set of coefficients. If the sum is insignificant but the set is significant, this suggests the variable has significant, but transitory, effects. When both are significant, there are permanent effects as well as possible transitory effects. Data for real GNP, GNP deflator, other checkable deposits, M1, M2, cyclically adjusted federal government expenditures, as well as the three-month Treasury Bill rate for Table IV, are from Citibase data tapes. Data on Venezuelan oil prices are from various issues of Platt's Oil Price Report, Oilgram News and Petroleum Intelligence Weekly.

Real Growth. The results shown on the left-hand side of Table I indicate that the M1A equation yields the lowest standard error (3.32), while the standard error for M1 (3.40) is somewhat higher and that for M2 is highest (3.54). Adjusted federal expenditures tend to exert significant negative effects on real growth. Money growth has a significant transitory effect when using 
TABLE I

Real GNP and Inflation Equations

Estimation: 1961Q1-82Q4

GNP82 Equations with Oil Shock

GNP Deflator Equations with Relative Oil Price

(Absolute t-statistics in parentheses)

\begin{tabular}{lccccccc} 
& \multicolumn{1}{c}{ GNP82 Growth Equations } & \multicolumn{3}{c}{$\begin{array}{c}\text { Inflation Equations } \\
\text { (GNP Deflator) }\end{array}$} \\
& M1A & M1 & M2 & M1A & M1 & M2 \\
\hline Constant & 5.50 & 6.41 & 3.93 & -1.59 & -0.89 & -3.41 \\
& $(3.80)$ & $(4.63)$ & $(1.92)$ & $(1.87)$ & $(1.18)$ & $(2.05)$ \\
Price Controls & 7.99 & 8.10 & 5.51 & -6.06 & -8.26 & -1.81 \\
& $(1.16)$ & $(1.14)$ & $(0.63)$ & $(1.75)$ & $(2.51)$ & $(0.36)$ \\
Credit Controls & & 11.01 & -10.51 & -11.63 & 0.68 & 0.30 & 0.58 \\
& $(3.23)$ & $(2.99)$ & $(3.22)$ & $(0.42)$ & $(0.19)$ & $(0.33)$
\end{tabular}

PDL Sums* (expenditures, money, and oil shock lagged one quarter):

\begin{tabular}{lcccccc} 
Expenditures & -0.23 & -0.28 & -0.40 & 0.23 & 0.01 & 0.39 \\
& $(1.54)^{\mathrm{b}}$ & $(1.68)^{\mathrm{a}}$ & $(2.68)^{\mathrm{d}}$ & $(2.13)^{\mathrm{a}}$ & $(0.07)$ & $(2.90)^{\mathrm{a}}$ \\
Money** & -0.09 & -0.23 & 0.36 & 1.06 & 1.21 & 0.65 \\
& $(0.41)^{\mathrm{f}}$ & $(0.89)^{\mathrm{d}}$ & $(1.51)$ & $(6.70)^{\mathrm{f}}$ & $(7.48)^{\mathrm{f}}$ & $(3.20)^{\mathrm{c}}$ \\
Oil Shock/ & -0.06 & 0.10 & -0.14 & 0.08 & 0.13 & 0.11 \\
Oil Price & $(0.27)$ & $(0.45)$ & $(0.59)$ & $(1.18)$ & $(1.97)^{\mathrm{a}}$ & $(1.16)^{\mathrm{a}}$ \\
Rho & n.a. & n.a. & n.a. & .09 & .04 & .27 \\
$\mathrm{R}^{2}$ & .37 & .34 & .29 & .70 & .72 & .62 \\
F & 7.37 & 6.52 & 5.36 & 25.86 & 27.96 & 18.42 \\
(n,d) & $(8,79)$ & $(8,79)$ & $(8,79)$ & $(8,78)$ & $(8,78)$ & $(8,78)$ \\
D.W. & 2.18 & 2.07 & 1.94 & 1.93 & 1.88 & 1.94 \\
SEE & 3.32 & 3.40 & 3.54 & 1.56 & 1.52 & 1.76 \\
\hline
\end{tabular}

*For PDL variables, an F-test is also given for the hypothesis that the parameters (expenditures, money, oil variable) are jointly zero, where $(a, b, c, d, e, f)=,(10,5,2.5,1,0.5,0.1)$ percent level.

**Money growth series adjusted for financial deregulation: M1A growth for 1981Q1 changed to -3.6 percent from -22.1 percent; M1 growth for $1981 Q 1$ changed to -3.8 percent from +1.7 percent; M2 growth for $1983 \mathrm{Q} 1$ changed to +9.9 percent from 19.8 percent. Adjustments based on unofficial estimates provided by staff of Federal Reserve Board of Governors.

Note: Expenditures and money concepts in GNP82 equations are second-degree polynomials with twelve lags and far-end constrained. The oil shock is third degree, twelve lags, with both ends constrained. The credit control dummy equals one in $1980 \mathrm{Q} 2$ and zero elsewhere. The price controls dummy equals +.143 in 1971 Q3-73Q1, -.143 in 1973Q2-74Q4, and zero elsewhere (see Darby [1982]). For GNP deflator equations, polynomial specifications are second degree, sixteen lags and far-end constrained. 
M1A and M1. For M2, neither permanent nor transitory effects are found. 10 This result may suggest that once other factors are considered, M2 contains little reliable information on the effects of money on short-term real growth, a point stressed anew by Jordan [1986, 8].

Table II displays the distributed-lag coefficients of the variables. In the equations for M1A and M1, money growth tends to exert a positive but diminishing effect initially and a progressively offsetting negative influence thereafter. All equations benefit from inclusion of the credit control dummy. The price controls dummy is not significant in any of the equations. The relative oil price variable enters the equations in distributed-lag form (third degree with both end points constrained), based on the previous discussion of this variable. In general, its lag configuration consists of significant negative values for about four quarters followed by consistently positive values. While the $t$-test on the coefficient sum and F-test on the coefficient set of the oil shock variable are not significant, this may be due to two factors. First, there were only two oil shocks over the sample period; and second, the 1973-74 oil shock coincided with the removal of price controls. Since the latter would have the same effect on real growth as the oil shock, there may be a multicollinearity problem compounded by too few degrees of freedom. Extending the sample to 1987 will be seen below to help resolve these questions.

Inflation. The right-hand side of Table I summarizes regressions of the quarterly percentage change (annualized) in the GNP deflator. Table III displays the individual coefficients for the polynomial lags. All regressions include dummies for 1971-74 price controls and for the 1982 credit controls. While the latter is insignificant, the price controls dummy is always negative and significant in the presence of M1A and M1 which, together with a positive sign in the real growth equation, suggests, as first reported by Darby [1982], that price controls led to overstatement of output as a result of understatement of price during the control period. The government expenditures variable tends to exert a positive and significant permanent effect in the M1A and $M 2$ equations, but is insignificant in the M1 equation. The coefficient sum of the relative oil price variable is more significant in the equation using M1 than in those using M1A or M2. Generally, significant effects of a change in the relative oil price last no more than four or five quarters.

The coefficient sums in Table I indicate that, consistent with long-run neutrality, the permanent effects of each monetary aggregate are within two standard deviations of unity. For all aggregates, the sum is approximately

10. In regressions (not reported) which used M1A and M2 less M1A, the coefficients on M1A are similar to those in the M1A equation of Table $\mathrm{I}$. The coefficients of M2 less M1A are positive and significant. As indicated above, this suggests that M2 may be dominated by its saving component. 


\section{TABLE II}

Real GNP Equations: Distributed-Lag Coefficients (Absolute t-statistics in parentheses)

\begin{tabular}{|c|c|c|c|c|c|c|c|c|c|}
\hline \multirow[b]{2}{*}{ Laq } & \multicolumn{3}{|c|}{$\begin{array}{c}\text { Money in } \\
\text { Equation Using: }\end{array}$} & \multicolumn{3}{|c|}{$\begin{array}{l}\text { Expenditure in } \\
\text { Equation Using: }\end{array}$} & \multicolumn{3}{|c|}{$\begin{array}{l}\text { Oil Shock in } \\
\text { Equation Using: }\end{array}$} \\
\hline & g M1A & M1 & M2 & M1A & M1 & M2 & M1A & M1 & M2 \\
\hline 1 & $\begin{array}{c}.286 \\
(3.938)\end{array}$ & $\begin{array}{r}.264 \\
(2.904)\end{array}$ & $\begin{array}{c}.155 \\
(1.992)\end{array}$ & $\begin{array}{c}.038 \\
(1.114)\end{array}$ & $\begin{array}{c}.035 \\
(0.995)\end{array}$ & $\begin{array}{r}.029 \\
(0.141)\end{array}$ & $\begin{array}{l}-.030 \\
(1.751)\end{array}$ & $\begin{array}{c}-.027 \\
(1.521)\end{array}$ & $\begin{array}{l}-.033 \\
(1.906)\end{array}$ \\
\hline 2 & $\begin{array}{c}.187 \\
(3.807)\end{array}$ & $\begin{array}{c}.167 \\
(2.623)\end{array}$ & $\begin{array}{c}.117 \\
(2.090)\end{array}$ & $\begin{array}{c}.017 \\
(0.647)\end{array}$ & $\begin{array}{c}.013 \\
(0.471)\end{array}$ & $\begin{array}{r}.004 \\
(0.853)\end{array}$ & $\begin{array}{l}-.045 \\
(1.652)\end{array}$ & $\begin{array}{c}-.040 \\
(1.416)\end{array}$ & $\begin{array}{c}-.054 \\
(1.886)\end{array}$ \\
\hline 3 & $\begin{array}{c}.102 \\
(3.204)\end{array}$ & $\begin{array}{c}.084 \\
(1.969)\end{array}$ & $\begin{array}{c}.084 \\
(2.149)\end{array}$ & $\begin{array}{l}-.001 \\
(.074)\end{array}$ & $\begin{array}{c}-.006 \\
(0.302)\end{array}$ & $\begin{array}{c}-.017 \\
(2.037)\end{array}$ & $\begin{array}{l}-.047 \\
(1.496)\end{array}$ & $\begin{array}{c}-.040 \\
(1.255)\end{array}$ & $\begin{array}{c}-.059 \\
(1.844)\end{array}$ \\
\hline 4 & $\begin{array}{c}.030 \\
(1.267)\end{array}$ & $\begin{array}{c}.014 \\
(0.470)\end{array}$ & $\begin{array}{c}.055 \\
(1.948)\end{array}$ & $\begin{array}{l}-.016 \\
(0.989)\end{array}$ & $\begin{array}{c}-.021 \\
(1.187)\end{array}$ & $\begin{array}{l}-.035 \\
(2.903)\end{array}$ & $\begin{array}{c}-.038 \\
(1.242)\end{array}$ & $\begin{array}{c}-.032 \\
(0.997)\end{array}$ & $\begin{array}{c}-.055 \\
(1.733)\end{array}$ \\
\hline 5 & $\begin{array}{c}-.027 \\
(1.053)\end{array}$ & $\begin{array}{c}-.042 \\
(1.478)\end{array}$ & $\begin{array}{c}.030 \\
(1.222)\end{array}$ & $\begin{array}{c}-.028 \\
(1.768)\end{array}$ & $\begin{array}{l}-.033 \\
(1.863)\end{array}$ & $\begin{array}{c}-.047 \\
(3.266)\end{array}$ & $\begin{array}{l}-.022 \\
(0.81)\end{array}$ & $\begin{array}{c}-.017 \\
(0.572)\end{array}$ & $\begin{array}{c}-.042 \\
(1.469)\end{array}$ \\
\hline 6 & $\begin{array}{c}-.072 \\
(2.216)\end{array}$ & $\begin{array}{c}-.084 \\
(2.542)\end{array}$ & $\begin{array}{c}.017 \\
(0.396)\end{array}$ & $\begin{array}{l}-.036 \\
(2.207)\end{array}$ & $\begin{array}{c}-.042 \\
(2.225)\end{array}$ & $\begin{array}{c}-.056 \\
(3.266)\end{array}$ & $\begin{array}{l}-.003 \\
(0.136)\end{array}$ & $\begin{array}{c}.002 \\
(0.073)\end{array}$ & $\begin{array}{c}-.025 \\
(0.941)\end{array}$ \\
\hline 7 & $\begin{array}{l}-.103 \\
(2.750)\end{array}$ & $\begin{array}{l}-.113 \\
(2.952)\end{array}$ & $\begin{array}{c}-.004 \\
(0.145)\end{array}$ & $\begin{array}{c}-.041 \\
(2.400)\end{array}$ & $\begin{array}{l}-.046 \\
(2.385)\end{array}$ & $\begin{array}{c}-.061 \\
(3.347)\end{array}$ & $\begin{array}{c}.017 \\
(0.699)\end{array}$ & $\begin{array}{c}.021 \\
(0.820)\end{array}$ & $\begin{array}{c}-.006 \\
(0.217)\end{array}$ \\
\hline 8 & $\begin{array}{l}-.120 \\
(3.019)\end{array}$ & $\begin{array}{l}-.128 \\
(3.122)\end{array}$ & $\begin{array}{l}-.015 \\
(0.465)\end{array}$ & $\begin{array}{l}-.042 \\
(2.476)\end{array}$ & $\begin{array}{l}-.047 \\
(2.450)\end{array}$ & $\begin{array}{l}-.061 \\
(3.327)\end{array}$ & $\begin{array}{r}.036 \\
(1.355)\end{array}$ & $\begin{array}{c}.039 \\
(1.392)\end{array}$ & $\begin{array}{c}.013 \\
(0.411)\end{array}$ \\
\hline 9 & $\begin{array}{l}-.123 \\
(3.178)\end{array}$ & $\begin{array}{l}-.130 \\
(3.203)\end{array}$ & $\begin{array}{l}-.021 \\
(0.664)\end{array}$ & $\begin{array}{l}-.040 \\
(2.502)\end{array}$ & $\begin{array}{l}-.045 \\
(2.474)\end{array}$ & $\begin{array}{l}-.057 \\
(3.278)\end{array}$ & $\begin{array}{c}.050 \\
(1.740)\end{array}$ & $\begin{array}{c}.051 \\
(1.706)\end{array}$ & $\begin{array}{c}.028 \\
(0.823)\end{array}$ \\
\hline 10 & $\begin{array}{c}-.113 \\
(3.276)\end{array}$ & $\begin{array}{c}-.118 \\
(3.247)\end{array}$ & $\begin{array}{c}-.023 \\
(0.796)\end{array}$ & $\begin{array}{c}-.035 \\
(2.506)\end{array}$ & $\begin{array}{c}-.039 \\
(2.478)\end{array}$ & $\begin{array}{c}-.049 \\
(3.225)\end{array}$ & $\begin{array}{c}.056 \\
(1.934)\end{array}$ & $\begin{array}{c}.057 \\
(1.858)\end{array}$ & $\begin{array}{c}.037 \\
(1.075)\end{array}$ \\
\hline 11 & $\begin{array}{c}-.089 \\
(3.376)\end{array}$ & $\begin{array}{c}-.092 \\
(3.272)\end{array}$ & $\begin{array}{c}-.020 \\
(0.889)\end{array}$ & $\begin{array}{c}-.027 \\
(2.500)\end{array}$ & $\begin{array}{c}-.030 \\
(2.474)\end{array}$ & $\begin{array}{c}-.037 \\
(3.177)\end{array}$ & $\begin{array}{c}.052 \\
(2.032)\end{array}$ & $\begin{array}{c}.052 \\
(1.930)\end{array}$ & $\begin{array}{c}.037 \\
(1.234)\end{array}$ \\
\hline 12 & $\begin{array}{c}-.051 \\
(3.400)\end{array}$ & $\begin{array}{c}-.053 \\
(3.287)\end{array}$ & $\begin{array}{c}-.012 \\
(0.958)\end{array}$ & $\begin{array}{c}-.015 \\
(2.492)\end{array}$ & $\begin{array}{c}-.017 \\
(2.467)\end{array}$ & $\begin{array}{c}-.021 \\
(3.133)\end{array}$ & $\begin{array}{c}.034 \\
(2.084)\end{array}$ & $\begin{array}{c}.034 \\
(1.964)\end{array}$ & $\begin{array}{r}.026 \\
(1.339)\end{array}$ \\
\hline
\end{tabular}


TABLE III

Inflation Equations: Distributed-Lag Coefficients

(Absolute t-statistics in parentheses)

\begin{tabular}{|c|c|c|c|c|c|c|c|c|}
\hline & 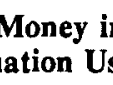 & & & & & & & $\begin{array}{l}\text { Price } \\
\text { sing: }\end{array}$ \\
\hline M1A & M1 & M2 & M1A & M1 & M2 & M1A & M1 & M2 \\
\hline $\begin{array}{cc}1 & -.003 \\
& (.095)\end{array}$ & (2.525) & $\begin{array}{c}.001 \\
(0.035)\end{array}$ & 133) & $\begin{array}{c}.001 \\
(.101)\end{array}$ & $(0.6$ & $\begin{array}{l}.022 \\
.925)\end{array}$ & $\begin{array}{c}.019 \\
(1.771)\end{array}$ & $\begin{array}{c}.037 \\
(2.680)\end{array}$ \\
\hline $\begin{array}{lc}2 & .021 \\
& (.863)\end{array}$ & $\begin{array}{l}.100 \\
(3.331)\end{array}$ & $\begin{array}{c}.015 \\
(0.412)\end{array}$ & $\begin{array}{l}.007 \\
0.518)\end{array}$ & $\begin{array}{l}.001 \\
(.106)\end{array}$ & $\begin{array}{r}.0 \\
(1.12\end{array}$ & $\begin{array}{l}.018 \\
1.970)\end{array}$ & $\begin{array}{c}.017 \\
(1.971)\end{array}$ & $\begin{array}{c}.030 \\
(2.694)\end{array}$ \\
\hline $\begin{array}{lc}3 \quad .042 \\
(2.361)\end{array}$ & $\begin{array}{c}.101 \\
(4.446)\end{array}$ & $\begin{array}{c}.027 \\
(1.216)\end{array}$ & $\begin{array}{c}.010 \\
(0.973)\end{array}$ & $\begin{array}{c}.001 \\
(.106)\end{array}$ & $\begin{array}{c}.023 \\
(1.681)\end{array}$ & $\begin{array}{c}.015 \\
(1.957)\end{array}$ & $\begin{array}{c}.015 \\
(2.160)\end{array}$ & $\begin{array}{c}.024 \\
(2.592)\end{array}$ \\
\hline $\begin{array}{lr}4 & .060 \\
(4.473)\end{array}$ & $\begin{array}{c}.101 \\
(5.876)\end{array}$ & $\begin{array}{c}.038 \\
(2.016)\end{array}$ & $\begin{array}{c}.014 \\
(1.446)\end{array}$ & $\begin{array}{c}.001 \\
(.099)\end{array}$ & $\begin{array}{c}.026 \\
(2.234)\end{array}$ & $\begin{array}{l}.012 \\
1.831)\end{array}$ & $\begin{array}{c}.014 \\
(2.264)\end{array}$ & $\begin{array}{c}.018 \\
(2.285)\end{array}$ \\
\hline $\begin{array}{lr}5 & .074 \\
& (6.295)\end{array}$ & $\begin{array}{c}.100 \\
(7.187)\end{array}$ & $\begin{array}{c}.046 \\
7.254)\end{array}$ & $\begin{array}{c}.016 \\
(1.852)\end{array}$ & 00 & $\begin{array}{r}.02 \\
(2.66\end{array}$ & $\begin{array}{l}.009 \\
.557)\end{array}$ & $\begin{array}{c}.012 \\
(2.201)\end{array}$ & $\begin{array}{c}.013 \\
(1.766)\end{array}$ \\
\hline $\begin{array}{cc}6 & 0.85 \\
& (6.703)\end{array}$ & $\begin{array}{c}.098 \\
(7.475)\end{array}$ & $\begin{array}{l}.053 \\
.205)\end{array}$ & $\begin{array}{c}.018 \\
(2.131)\end{array}$ & $(.072)$ & $\begin{array}{r}.03 \\
(2.90\end{array}$ & $\begin{array}{c}.007 \\
(1.183)\end{array}$ & $\begin{array}{c}.011 \\
(1.972)\end{array}$ & $\begin{array}{c}.009 \\
(1.164)\end{array}$ \\
\hline $7 \begin{array}{c}.094 \\
(6.324)\end{array}$ & $\begin{array}{c}.094 \\
(6.746)\end{array}$ & $\begin{array}{l}.057 \\
3.354)\end{array}$ & $\begin{array}{c}.020 \\
(2.282)\end{array}$ & $\begin{array}{c}.001 \\
(.058)\end{array}$ & $\begin{array}{c}.033 \\
(2.970)\end{array}$ & $\begin{array}{c}.005 \\
(0.803)\end{array}$ & $\begin{array}{c}.009 \\
(1.668)\end{array}$ & $\begin{array}{r}.005 \\
(0.624)\end{array}$ \\
\hline $\begin{array}{lc}8 & .098 \\
(5.849)\end{array}$ & $\begin{array}{r}.090 \\
(5.792)\end{array}$ & $\begin{array}{c}.060 \\
(3.331)\end{array}$ & $\begin{array}{c}.021 \\
(2.343)\end{array}$ & 00 & 0 & $\begin{array}{l}.003 \\
0.479)\end{array}$ & $\begin{array}{c}.008 \\
(1.376)\end{array}$ & $\begin{array}{r}.0 \\
(0.1\end{array}$ \\
\hline $9 \begin{array}{l}.100 \\
(5.455)\end{array}$ & $\begin{array}{c}.084 \\
(4.989)\end{array}$ & $\begin{array}{c}.061 \\
(3.243)\end{array}$ & $\begin{array}{c}.021 \\
(2.352)\end{array}$ & $\begin{array}{l}.000 \\
(.036)\end{array}$ & $\begin{array}{c}.033 \\
(2.868)\end{array}$ & $\begin{array}{c}.001 \\
(0.223)\end{array}$ & $\begin{array}{c}.007 \\
(1.129)\end{array}$ & $\begin{array}{c}-.001 \\
(0.121)\end{array}$ \\
\hline $10 \begin{array}{r}.099 \\
(5.149)\end{array}$ & $\begin{array}{c}.078 \\
(4.376)\end{array}$ & $\begin{array}{c}.060 \\
(3.142)\end{array}$ & $\begin{array}{c}.020 \\
(2.335)\end{array}$ & $\begin{array}{l}.000 \\
(.028)\end{array}$ & $\begin{array}{c}.032 \\
(2.783)\end{array}$ & $\begin{array}{c}.000 \\
(0.003)\end{array}$ & $\begin{array}{c}.005 \\
(0.931)\end{array}$ & $\begin{array}{c}-.003 \\
(0.362)\end{array}$ \\
\hline $11 \quad .094$ & $\begin{array}{c}.070 \\
(3.913)\end{array}$ & $\begin{array}{c}.057 \\
(3.045)\end{array}$ & $\begin{array}{c}.019 \\
(2.307)\end{array}$ & $\begin{array}{l}.000 \\
(.021)\end{array}$ & $\begin{array}{c}.030 \\
(2.699)\end{array}$ & $\begin{array}{c}-.001 \\
(0.126)\end{array}$ & $\begin{array}{c}.004 \\
(0.772)\end{array}$ & $\begin{array}{c}-.004 \\
(0.545)\end{array}$ \\
\hline $12 \quad \begin{array}{c}.087 \\
(4.725)\end{array}$ & $\begin{array}{c}.061 \\
(3.557)\end{array}$ & $\begin{array}{c}.052 \\
(2.959)\end{array}$ & $\begin{array}{c}.018 \\
(2.275)\end{array}$ & $\begin{array}{l}.00 \\
. .01\end{array}$ & $\begin{array}{c}.027 \\
(2.622)\end{array}$ & $\begin{array}{l}-.002 \\
(0.245)\end{array}$ & $\begin{array}{c}.003 \\
(0.646)\end{array}$ & $\begin{array}{l}-.005 \\
(0.687)\end{array}$ \\
\hline $13 \begin{array}{r}.076 \\
(4.575)\end{array}$ & $\begin{array}{r}.051 \\
(3.278\end{array}$ & $\begin{array}{c}.045 \\
(2.885)\end{array}$ & $\begin{array}{c}.015 \\
(2.243)\end{array}$ & $\begin{array}{l}.000 \\
(.012)\end{array}$ & $\begin{array}{r}.0 \\
(2.5\end{array}$ & $\begin{array}{c}-.002 \\
(0.340)\end{array}$ & $\begin{array}{c}.003 \\
(0.542)\end{array}$ & $\begin{array}{c}-.005 \\
(0.799)\end{array}$ \\
\hline $14 \begin{array}{c}.061 \\
(4.452)\end{array}$ & $\begin{array}{r}.04 \\
(3.05\end{array}$ & $\begin{array}{c}.037 \\
(2.820)\end{array}$ & $\begin{array}{c}.013 \\
(2.212)\end{array}$ & $\begin{array}{l}.000 \\
(.008)\end{array}$ & $\begin{array}{c}.019 \\
(2.492)\end{array}$ & $\begin{array}{l}-.002 \\
(0.417)\end{array}$ & $\begin{array}{c}.002 \\
(0.458)\end{array}$ & $\begin{array}{c}-.005 \\
(0.890)\end{array}$ \\
\hline $15 \begin{array}{c}.044 \\
(4.350)\end{array}$ & $\begin{array}{r}.028 \\
(2.871\end{array}$ & $\begin{array}{r}.026 \\
(2.764\end{array}$ & $\begin{array}{r}.00 \\
(2.18\end{array}$ & $\begin{array}{r}.000 \\
. .005\end{array}$ & $\begin{array}{r}.01 \\
(2.43\end{array}$ & $\begin{array}{c}-.001 \\
(0.480)\end{array}$ & $\begin{array}{c}.001 \\
(0.387)\end{array}$ & $\begin{array}{c}-.004 \\
(0.964)\end{array}$ \\
\hline $16 \begin{array}{c}.024 \\
(4.265)\end{array}$ & $\begin{array}{c}.014 \\
(2.720)\end{array}$ & $\begin{array}{c}.014 \\
(2.716)\end{array}$ & $\begin{array}{c}.005 \\
(2.157)\end{array}$ & $\begin{array}{c}.000 \\
(.002)\end{array}$ & $\begin{array}{c}.007 \\
(2.391)\end{array}$ & $\begin{array}{l}-.001 \\
(0.532)\end{array}$ & $\begin{array}{c}.001 \\
(0.328)\end{array}$ & $\begin{array}{c}-.002 \\
(1.026)\end{array}$ \\
\hline
\end{tabular}


equal to the ratio of inflation to money growth over the sample period. For a regression (not reported) together using M1A and M2 less M1A, the coefficient sum for the latter is insignificant, again suggesting that the savings component may be a source of measurement error in the reported equation using M2. Over the estimation interval 1961Q1-82Q4, M1 tended to perform only marginally better than M1A, and both performed better than M2, based upon $\mathbf{R}^{2}$ and standard error criteria.

One final observation is noted. When the real growth and inflation equations are combined, results for the M1A equations are consistent with the standard St. Louis equation using nominal GNP growth as the dependent variable. The expenditure effect is about zero and the money growth effect is about unity. For M1 and M2, the expenditure effect is negative, while the money growth effect is unity.

Predictions from Indicator Equations. Table II reports out-of-sample statistics for predictions of real GNP growth and inflation for eighteen quarters, $1983 \mathrm{Q} 1-87 \mathrm{Q} 2$. The growth and inflation predictions are also combined to compute prediction statistics for nominal GNP growth. Since an autocorrelation correction is used in the inflation equations, both static and dynamic prediction statistics are computed for inflation and derived nominal GNP growth. The dynamic predictions use the previously predicted (rather than lagged actual) value of the endogenous variable. For comparison purposes, as obtained in Blue Chip Economic Indicators, two sets of prediction statistics for the Blue Chip consensus forecasts are included. The first is a series of one-quarter "static" forecasts, based on the forecasts appearing in the issue dated in the first month of each quarter. The second set consists of "dynamic" forecasts for one through eight quarters ahead appearing in the January 1983 and January 1985 issues; the January 1987 issue provides forecasts for 1987Q1-Q2. This places the Blue Chip multiple-quarter forecasts on a more equal footing with the dynamic forecasts of the indicator equations. The comparison still suffers, however, because Blue Chip forecasters did not have knowledge of actual money and expenditure growth. Figure 3 compares actual and predicted outcomes for real growth, inflation and nominal GNP growth.

Real GNP Growth. Summary statistics indicate that M1A is the superior predictive indicator of movements in real GNP. Its root mean square error (RMSQE) is 38 basis points lower than its in-sample standard error, and 72 and 107 basis points lower than the RMSQE for M1 and M2, respectively. Its mean absolute error (MAE) is 64 and 59 basis points lower than those for M1 and M2, respectively. The mean error (ME), which is a measure of forecast bias, indicates that M1A overpredicted real GNP growth by an average of .45 percentage points, while $M 1$ and $M 2$ respectively underpredicted by 0.88 and 1.49 percentage points. M1A has a smaller RMSQE than both 
FIGURE 3

Panel a

REAL GNP GROWTH PREDICTIONS

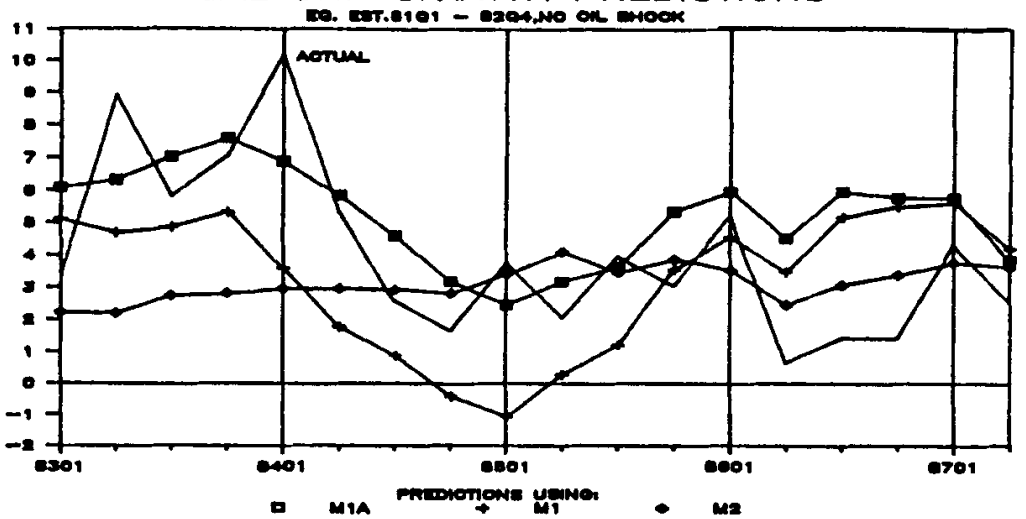

Panel b

INFLATION (DEFLATOR) PREDICTIONS

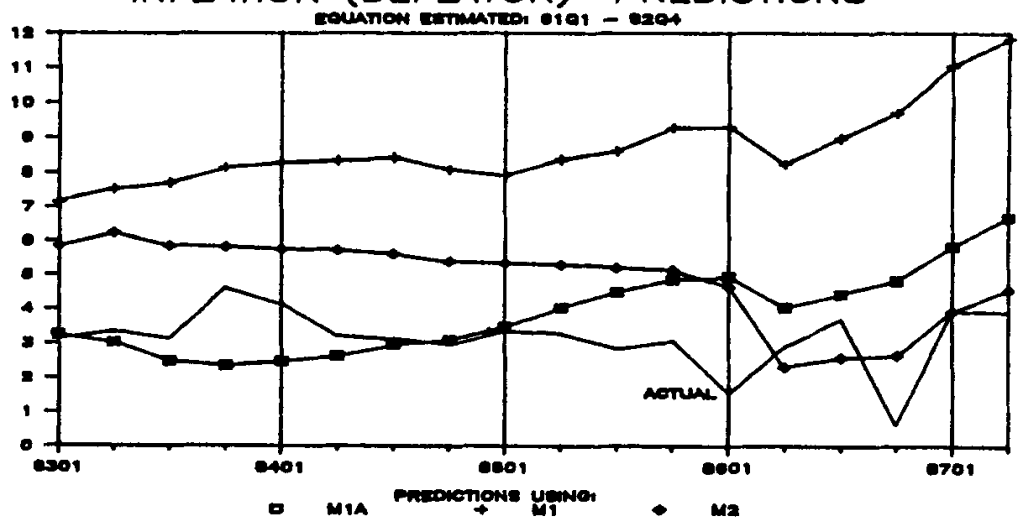

Panel $\mathrm{C}$

NOMINAL GNP GROWTH PREDICTIONS

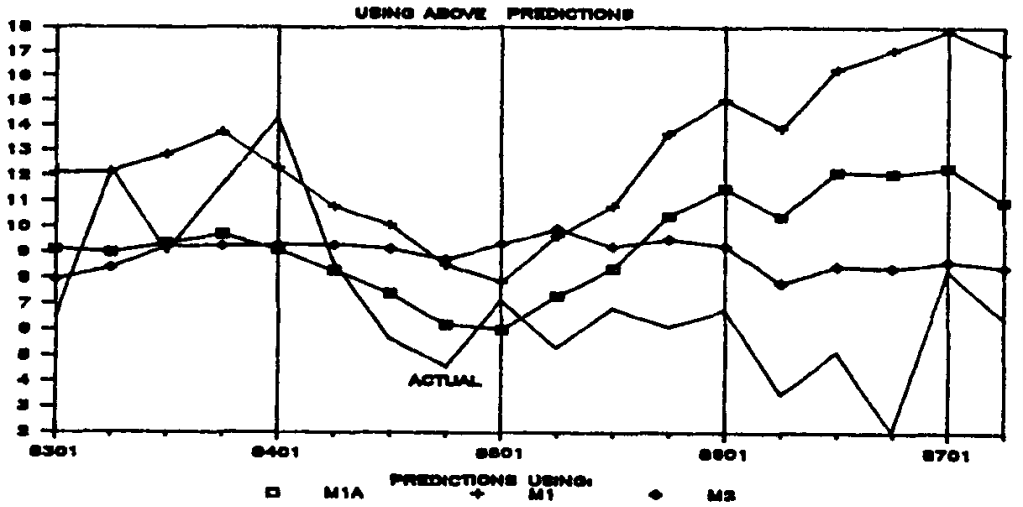


the static and dynamic Blue Chip consensus. Figure 3 plots real growth predictions. The M1A forecasts are able to capture the 1986 slowdown, and best indicate the rapid recovery of 1983 and the slowing of real growth in 1984-85. M1 systematically underestimates growth in 1983-85, while M2 produces predictions which are relatively invariant over the period. M2 predictions tend to miss short-term fluctuations until the oil shock variable "kicks in" and lowers the real growth path during 1986. However, as shown by Darby, Mascaro and Marlow [1987], the relative superiority of M1A as an indicator of the real economy is independent of whether or not the influence of relative oil price shocks is taken into account.

In summary, if only the pattern of money and expenditure growth are considered, it appears that M1A is a useful indicator of the pattern of real GNP growth and is clearly superior to M1 and M2. Moreover, the empirical results suggest that the savings component of M2 may endow this aggregate with a different character when compared to aggregates which are more dominated by transactions motives. Of course, low overall in-sample correlation with quarterly real GNP growth for all three equations indicates that quarter-to-quarter changes in real GNP contain an essential element of randomness which makes any point (as opposed to range) forecast necessarily imprecise.

Inflation. The out-of-sample prediction statistics for inflation, shown in Table IV, are for both static and dynamic forecasts. They indicate the extent of the deterioration of $\mathrm{Ml}$ as an inflation indicator, and suggest the relative superiority of M1A over M1 or M2 as an indicator of inflation over 1983Q1-87Q2.

The static RMSQE is 1.69 for M1A, 5.56 for M1, and 1.71 for M2. The mean errors indicate relatively small average bias for M1A $(-0.68)$ compared to the biases for M1 (-5.37) and M2 (-1.27). In the case of dynamic out-ofsample forecasts, M1A remains the superior indicator with respect to showing the lowest RMSQE and mean error.

Figure 3 displays the dynamic predictions of inflation. In the period 1983$85, M 1$ and $M 2$ failed to indicate the extent of the disinflation, while the behavior of M1A came closest to indicating the disinflation since 1981. In the case of M1, the rapid growth of OCDs may have induced measurement error which has impaired M1 but not M1A. The figures indicate that, beginning at the end of 1985 , the M1A predictions show a strong upward trend, while the trend is slightly declining for $\mathrm{M} 2$ forecasts. This is revisited in section IV.

In sum, a straightforward horse race suggests that M1A has retained its ability to serve as a useful indicator of inflation while M1 presently seems to be of little use. However, given that redefinition of the monetary aggregates relates current $M 1$ to "old" $M 2$, it may not be surprising that current M1 does not behave like "old" M1 (current M1A). Of course, this does not rule out the possibility that M1 may subsequently resume its close association 
Prediction Statistics: 1983Q1-87Q2

\begin{tabular}{|c|c|c|c|c|c|}
\hline & & M1A & M1 & M2 & Blue Chip \\
\hline \multicolumn{5}{|l|}{ Real GNP: } & (static/dynamic) \\
\hline RMSQE & & 1.94 & 2.66 & 3.01 & $2.35 / 2.29$ \\
\hline MAE & & 1.53 & 2.17 & 2.12 & $1.79 / 1.71$ \\
\hline ME & & -0.45 & 0.88 & 1.49 & $0.33 / 0.68$ \\
\hline \multicolumn{6}{|l|}{ Inflation: } \\
\hline RMSQE & $\begin{array}{l}\text { Static } \\
\text { Dynamic }\end{array}$ & $\begin{array}{l}1.69 \\
1.79\end{array}$ & $\begin{array}{l}5.56 \\
5.75\end{array}$ & $\begin{array}{l}1.71 \\
1.71\end{array}$ & $\begin{array}{l}1.17 \\
2.12\end{array}$ \\
\hline MAE & $\begin{array}{l}\text { Static } \\
\text { Dynamic }\end{array}$ & $\begin{array}{l}1.25 \\
1.36\end{array}$ & $\begin{array}{l}5.37 \\
5.56\end{array}$ & $\begin{array}{l}1.59 \\
1.91\end{array}$ & $\begin{array}{l}1.02 \\
1.87\end{array}$ \\
\hline $\mathrm{ME}$ & $\begin{array}{l}\text { Static } \\
\text { Dynamic }\end{array}$ & $\begin{array}{l}-0.68 \\
-0.73\end{array}$ & $\begin{array}{l}-5.37 \\
-5.36\end{array}$ & $\begin{array}{l}-1.27 \\
-1.72\end{array}$ & $\begin{array}{l}-0.67 \\
-1.71\end{array}$ \\
\hline \multicolumn{6}{|c|}{ Nominal GNP (implied by above predictions for components): } \\
\hline RMSQE & $\begin{array}{l}\text { Static } \\
\text { Dynamic }\end{array}$ & $\begin{array}{l}3.13 \\
3.23\end{array}$ & $\begin{array}{l}5.71 \\
5.89\end{array}$ & $\begin{array}{l}2.82 \\
2.82\end{array}$ & $\begin{array}{l}2.46 \\
2.95\end{array}$ \\
\hline MAE & $\begin{array}{l}\text { Static } \\
\text { Dynamic }\end{array}$ & $\begin{array}{l}2.68 \\
2.78\end{array}$ & $\begin{array}{l}4.84 \\
5.00\end{array}$ & $\begin{array}{l}2.37 \\
2.37\end{array}$ & $\begin{array}{l}2.02 \\
2.45\end{array}$ \\
\hline ME & $\begin{array}{l}\text { Static } \\
\text { Dynamic }\end{array}$ & $\begin{array}{l}-1.13 \\
-1.18\end{array}$ & $\begin{array}{l}-4.49 \\
-4.69\end{array}$ & $\begin{array}{r}0.23 \\
-0.23\end{array}$ & $\begin{array}{l}-0.35 \\
-1.03\end{array}$ \\
\hline
\end{tabular}

with inflation. But based on data currently available, the behavior of M1 extending back to 1982 appears less related to that of inflation through mid1987.

Nominal GNP Growth. Forecast statistics drawn from nominal GNP growth are generated by combining the separate forecasts for real growth and inflation. All the prediction criteria indicate, as before, the break from the historical relation between M1 and nominal GNP for the post-sample period. Based on the above results, the changed relation appears attributable to the M1-inflation link.

The prediction statistics of Table IV indicate that the nominal GNP-M2 relation is slightly better than that using M1A. At first, this appears to be a curious result. For dynamic predictions, the RMSQE for M2 is about 41 basis points lower than that for M1A. Part of the reason for the somewhat better 
prediction statistics for M2 is that the downward bias in the real growth-M2 relation is offset by the upward bias in the inflation-M2 relation. Another reason is the relative constancy in the predictions using $M 2$, as indicated in panel $\mathrm{c}$ of Figure 3.

\section{TESTS FOR STRUCTURAL CHANGE}

Three approaches examine whether structural change has occurred with respect to the real growth and inflation equations estimated to 1982Q4. In the first approach the equations of the previous section are reestimated to 1987Q2 and a standard F-test is applied based on the ratio of residual sums of squares adjusted for degrees of freedom - the Chow test (see Chow [1960] or Fisher [1970]). A second approach tests for structural change by adding an intercept shift over 1983Q1-87Q2. A third approach reestimates the equations of the previous section to $1980 \mathrm{Q} 2$ and computes out-of-sample forecast statistics over 1980Q3-87Q2 and over 1983Q1-87Q2. The latter are then compared to in-sample statistics and to the out-of-sample forecast statistics of the equations estimated to $1982 \mathrm{Q} 4$.

With respect to the first and second approaches, a question arises as to whether 1983Q1 is an appropriate starting point to test for structural change since major financial deregulation was initiated at the start of 1981. If the structural changes were primarily transitional, induced by the onset of deregulation, the first two tests may be relatively insensitive and determine no structural change, since the equations estimated to the cycle trough (1982Q4) contain the quarters when most of the "one-time" transitional effects should have occurred. Thus, the first two tests may be more sensitive to "permanent" changes which have persisted into $1987 \mathrm{Q} 2$. Isolation of transitional effects is important but inherently more difficult to quantify. The use of a shiftadjusted data in 1981Q1 for M1A and M1 and in 1983Q1 for M2 is one way to account for transitional effects. ${ }^{11}$ The third approach, estimating the equations to $1980 \mathrm{Q} 2$ and computing out-of-sample forecasts in the two intervals 1980Q3-82Q4 and 1983Q1-87Q2, offers a better chance of discriminating between transitional and permanent change. That is, if the changes are transitional, then forecast statistics over 1983-87 should not deteriorate in any marked way relative to the in-sample standard errors to $1980 \mathrm{Q} 2$ and to the forecast statistics drawn from the equations estimated to $1982 \mathrm{Q} 4$.

11. Other approaches to capturing the transitional changes have been tried. For example, in the San Francisco Federal Reserve monthly model of money demand, a ramp function taking the consecutive values one through twelve in the months of 1981, and twelve thereafter, is entered together with the same variable squared and then cubed (see Judd [1983]). We have refrained from this kind of procedure, not through intrinsic objection, but to preclude the possibility that our results would be heavily dependent on such devices. 
Real GNP and Inflation Equations

\begin{tabular}{|c|c|c|c|c|c|c|}
\hline \multicolumn{4}{|c|}{$\begin{array}{l}\text { Estimation: } 1961 \mathrm{Q} 1-87 \mathrm{Q} 2 \\
\text { A: F-test for hypothesis of no structural change } \\
\text { B: Intercept shift term } \\
\text { (Absolute t-statistics in parentheses) }\end{array}$} & \multirow{2}{*}{\multicolumn{3}{|c|}{ Set B }} \\
\hline & \multicolumn{3}{|c|}{ Set $A$} & & & \\
\hline & M1A & M1 & M2 & M1A & M1 & M2 \\
\hline Constant & $\begin{array}{c}5.62 \\
(4.22)\end{array}$ & $\begin{array}{c}6.24 \\
(4.81)\end{array}$ & $\begin{array}{c}3.73 \\
(1.92)\end{array}$ & $\begin{array}{c}5.72 \\
(4.25)\end{array}$ & $\begin{array}{c}6.50 \\
(4.96)\end{array}$ & $\begin{array}{c}3.63 \\
(1.88)\end{array}$ \\
\hline Price Controls & $\begin{array}{c}7.47 \\
(1.18)\end{array}$ & $\begin{array}{c}7.56 \\
(1.13)\end{array}$ & $\begin{array}{c}6.74 \\
(0.80)\end{array}$ & $\begin{array}{c}7.35 \\
(1.16)\end{array}$ & $\begin{array}{c}7.91 \\
(1.18)\end{array}$ & $\begin{array}{c}5.75 \\
(0.68)\end{array}$ \\
\hline Credit Controls & $\begin{array}{r}-10.82 \\
(3.41)\end{array}$ & $\begin{array}{r}-10.93 \\
(3.28)\end{array}$ & $\begin{array}{r}-11.62 \\
(3.33)\end{array}$ & $\begin{array}{r}-10.81 \\
(3.39)\end{array}$ & $\begin{array}{r}-10.59 \\
(3.17)\end{array}$ & $\begin{array}{r}-11.50 \\
(3.33)\end{array}$ \\
\hline $\mathrm{d} 8387$ & n.a. & n.a. & n.a. & $\begin{array}{c}-0.54 \\
(0.57)\end{array}$ & $\begin{array}{c}1.47 \\
(1.22)\end{array}$ & $\begin{array}{c}1.39 \\
(1.48)\end{array}$ \\
\hline
\end{tabular}

PDL Sums* (expenditures, money, and oil shock lagged one quarter):

\begin{tabular}{|c|c|c|c|c|c|c|}
\hline Expenditures & $\begin{array}{c}-0.21 \\
(1.65)^{b}\end{array}$ & $\begin{array}{l}-0.30 \\
(2.21)^{c}\end{array}$ & $\begin{array}{l}-0.41 \\
(2.89)^{d}\end{array}$ & $\begin{array}{l}-0.21 \\
(1.63)^{\mathrm{a}}\end{array}$ & $\begin{array}{l}-0.24 \\
(1.70)^{b}\end{array}$ & $\begin{array}{l}-0.38 \\
(2.73)^{d}\end{array}$ \\
\hline Money & $\begin{array}{c}0.17 \\
(0.86)^{f}\end{array}$ & $\begin{array}{l}-0.10 \\
(0.57)^{f}\end{array}$ & $\begin{array}{c}0.41 \\
(1.80)^{\mathrm{a}}\end{array}$ & $\begin{array}{l}0.18 \\
(0.92)^{f}\end{array}$ & $\begin{array}{l}-0.28 \\
(1.22)^{f}\end{array}$ & $\begin{array}{c}0.37 \\
(1.62)^{a}\end{array}$ \\
\hline Oil Shock & $\begin{array}{l}-0.04 \\
(0.23)^{c}\end{array}$ & $\begin{array}{l}-0.02 \\
(0.10)^{c}\end{array}$ & $\begin{array}{c}-0.14 \\
(0.69)\end{array}$ & $\begin{array}{l}-0.05 \\
(0.28)^{b}\end{array}$ & $\begin{array}{l}-0.02 \\
(0.08)^{c}\end{array}$ & $\begin{array}{l}-0.19 \\
(0.76)^{\mathrm{a}}\end{array}$ \\
\hline$\overline{\mathbf{R}}^{2}$ & .39 & .33 & .26 & .39 & .33 & .27 \\
\hline $\begin{array}{l}\text { F } \\
(n, d)\end{array}$ & $\begin{array}{c}9.37 \\
(8,97)\end{array}$ & $\begin{array}{c}7.47 \\
(8,97)\end{array}$ & $\begin{array}{c}5.67 \\
(8,97)\end{array}$ & $\begin{array}{c}8.31 \\
(9,96)\end{array}$ & $\begin{array}{c}6.83 \\
(9,96)\end{array}$ & $\begin{array}{c}5.35 \\
(9,96)\end{array}$ \\
\hline D.W. & 2.15 & 1.97 & 1.80 & 2.17 & 2.00 & 1.84 \\
\hline SEE & 3.11 & 3.26 & 3.42 & 3.12 & 3.25 & 3.39 \\
\hline \multicolumn{7}{|c|}{ F-tests for hypothesis of no structural change: } \\
\hline Computed F & 0.32 & 0.53 & 0.63 & n.a. & n.a. & n.a. \\
\hline Critical F: $\begin{aligned} .95 & = \\
.99 & =\end{aligned}$ & $\begin{array}{l}1.95 \\
2.54\end{array}$ & $\begin{array}{l}1.95 \\
2.54\end{array}$ & $\begin{array}{l}1.95 \\
2.54\end{array}$ & $\begin{array}{l}\text { n.a. } \\
\text { n.a. }\end{array}$ & $\begin{array}{l}\text { n.a. } \\
\text { n.a. }\end{array}$ & $\begin{array}{l}\text { n.a. } \\
\text { n.a. }\end{array}$ \\
\hline
\end{tabular}

*For PDL variables, an F-test is given for the hypothesis that the parameters for each set (expenditures, money, oil variable) are jointly zero: $(a, b, c, d, e, f)=,(10,5,2.5,1,0.5,0.1)$ percent level. 
Real GNP. Table V presents regressions estimated to 1987Q2. Set A, which repeats the specification of Table I, shows F-tests for the null hypothesis of no structural change. Set B adds an intercept shift term D8387 for 1983Q1$87 \mathrm{Q} 2$ as an alternative test for structural change.

The F-tests of set A fail to show structural change when using any of the monetary aggregates. Inspection of individual coefficients indicates that there are no statistically significant changes among coefficients. The alternative test shown in set $B$ indicates that the intercept shift is significant at the 10 percent confidence level for the equations using $M 1$ and M2, but not for those using M1A. In addition, inclusion of the intercept shift term in set $B$ leads to approximate equality between the coefficient structures over the two estimation intervals to $1982 \mathrm{Q} 4$ and $1987 \mathrm{Q} 2$.

The absence of structural change in the equation using M1A, combined with its relative predictive superiority, probably reflects the dominance of the random component rather than the systematic component of money growth in influencing short-term fluctuations in real growth, as previously found by Barro [1981]. This evidence suggests that the money-real growth relation has not been affected by deregulation.

Inflation. Table VI is analogous to the one which examined structural change in real GNP. In set A, the F-statistics indicate that the null hypothesis of no structural change can be rejected for the equations using M1 at the 96 percent confidence level. The equations using M1A or M2 cannot reject the hypothesis; some changes occur among the coefficients of set $B$ relative to regressions in the shorter interval, but these are generally not significant. The intercept shift term in set B is significant for all three aggregates, but larger in absolute value for M1 and M2. Its inclusion results in a coefficient pattern which is approximately the same, relative to the equations estimated over the shorter interval, for M1A, M1, and M2.

Based on the inflation regressions which use M1, it is suggested by the results of set $B$ that the $\mathrm{M1}$-inflation relationship has experienced a downward shift of about five percentage points. This is about the same magnitude as the post-sample RMSQE or MAE indicated in Table I. The intercept shift is also of the same magnitude and sign as the mean error found for M1 in Table IV. Interestingly, the average growth of M1 since 1978 has been about three percentage points higher than M1A; M1A growth averaged 5 percent while M1 averaged 8 percent. Since 1982, and using one-quarter lags as were used in the regressions, M1A has grown 5.7 percent and M1 has grown 9.7 percent, or a difference of four percentage points. ${ }^{12}$

12. Recently, Rasche [1987] found a significant downward shift in $M 1$ velocity of about this magnitude. Using data adjusted for the nationwide introduction of NOW accounts in 1981Q1, he dates the start of the shift in early 1982, but can find no reasonable explanation for the shift. Since Rasche does not find a significant shift in M1A velocity, it may be that the shift he finds using $M 1$ reflects the differential growth of M1 versus M1A due to the relatively more rapid growth of interest-bearing deposits in M1. 
Inflation Equations (GNP Deflator)

\begin{tabular}{|c|c|c|c|c|c|c|}
\hline \multicolumn{7}{|c|}{$\begin{array}{l}\text { Estimation: } 1961 \mathrm{Q} 1-87 \mathrm{Q} 2 \\
\text { A: F-test for hypothesis of no structural change } \\
\text { B: Intercept shift term } \\
\text { (Absolute t-statistics in parentheses) }\end{array}$} \\
\hline & \multicolumn{3}{|c|}{ SetA } & \multicolumn{3}{|c|}{ Set B } \\
\hline & M1A & M1 & $\mathbf{M 2}$ & M1A & M1 & M2 \\
\hline Constant & $\begin{array}{c}1.27 \\
(1.44)\end{array}$ & $\begin{array}{c}0.79 \\
(0.58)\end{array}$ & $\begin{array}{c}-2.17 \\
(1.13)\end{array}$ & $\begin{array}{c}-1.37 \\
(1.58)\end{array}$ & $\begin{array}{c}-0.85 \\
(1.15)\end{array}$ & $\begin{array}{c}-3.33 \\
(2.03)\end{array}$ \\
\hline Price Controls & $\begin{array}{l}-4.67 \\
(1.36)\end{array}$ & $\begin{array}{c}-6.49 \\
(1.37)\end{array}$ & $\begin{array}{c}-3.59 \\
(0.69)\end{array}$ & $\begin{array}{c}-5.43 \\
(1.58)\end{array}$ & $\begin{array}{c}-7.04 \\
(2.24)\end{array}$ & $\begin{array}{c}-2.72 \\
(0.57)\end{array}$ \\
\hline Credit Controls & $\begin{array}{c}0.64 \\
(0.41)\end{array}$ & $\begin{array}{c}0.47 \\
(0.29)\end{array}$ & $\begin{array}{c}0.67 \\
(0.41)\end{array}$ & $\begin{array}{c}0.69 \\
(0.45)\end{array}$ & $\begin{array}{c}0.37 \\
(0.24)\end{array}$ & $\begin{array}{c}0.78 \\
(0.48)\end{array}$ \\
\hline D8387 & n.a. & n.a. & n.a. & $\begin{array}{c}-0.82 \\
(1.46)\end{array}$ & $\begin{array}{c}-4.64 \\
(7.13)\end{array}$ & $\begin{array}{c}-2.00 \\
(2.80)\end{array}$ \\
\hline \multicolumn{7}{|c|}{ PDL Sums* (expenditures, money, and oil price lagged one quarter): } \\
\hline Expenditures & $\begin{array}{c}0.27 \\
(2.77)^{\mathrm{c}}\end{array}$ & $\begin{array}{c}0.20 \\
(1.17)\end{array}$ & $\begin{array}{c}0.29 \\
(1.88)\end{array}$ & $\begin{array}{c}0.31 \\
(3.11)^{d}\end{array}$ & $\begin{array}{c}0.12 \\
(1.23)\end{array}$ & $\begin{array}{c}0.35 \\
(2.70)^{\mathrm{a}}\end{array}$ \\
\hline Money & $\underset{(6.85)^{\mathrm{f}}}{0.85}$ & $\begin{array}{c}0.41 \\
(2.37)^{\mathrm{a}}\end{array}$ & $\begin{array}{c}0.57 \\
(2.48)^{\mathrm{a}}\end{array}$ & $\begin{array}{c}0.83 \\
(6.76)^{f}\end{array}$ & $\begin{array}{c}0.99 \\
(7.94)^{\mathrm{f}}\end{array}$ & $\begin{array}{c}0.69 \\
(3.51)^{d}\end{array}$ \\
\hline Oil Price & $\begin{array}{c}0.16 \\
(2.42)^{\mathrm{e}}\end{array}$ & $\begin{array}{c}0.27 \\
(2.50)^{c}\end{array}$ & $\begin{array}{c}0.18 \\
(1.95)^{b}\end{array}$ & $\begin{array}{c}0.13 \\
(1.94)^{c}\end{array}$ & $\begin{array}{c}0.16 \\
(2.56)^{d}\end{array}$ & $\begin{array}{c}0.07 \\
(0.83)^{\mathrm{a}}\end{array}$ \\
\hline Rho & .15 & .44 & .41 & .14 & .06 & .31 \\
\hline $\mathrm{R}^{2}$ & .69 & .61 & .62 & .69 & .71 & .63 \\
\hline $\begin{array}{l}F \\
(n, d)\end{array}$ & $\begin{array}{c}30.02 \\
(8,96)\end{array}$ & $\begin{array}{c}21.61 \\
(8,96)\end{array}$ & $\begin{array}{c}21.83 \\
(8,96)\end{array}$ & $\begin{array}{c}27.23 \\
(9,95)\end{array}$ & $\begin{array}{c}29.67 \\
(9,95)\end{array}$ & $\begin{array}{c}21.35 \\
(9,95)\end{array}$ \\
\hline D.W. & 1.93 & 2.10 & 2.07 & 1.93 & 1.93 & 2.00 \\
\hline SEE & 1.53 & 1.71 & 1.17 & 1.52 & 1.48 & 1.66 \\
\hline \multicolumn{7}{|c|}{ F-tests for hypothesis of no structural change: } \\
\hline Computed F & 0.80 & 2.46 & 0.71 & n.a. & n.a. & n.a. \\
\hline Critical F: $\begin{aligned} .95 & = \\
.99 & =\end{aligned}$ & $\begin{array}{l}1.98 \\
2.60\end{array}$ & $\begin{array}{l}1.98 \\
2.60\end{array}$ & $\begin{array}{l}1.98 \\
2.60\end{array}$ & $\begin{array}{l}\text { n.a. } \\
\text { n.a. }\end{array}$ & $\begin{array}{l}\text { n.a. } \\
\text { n.a. }\end{array}$ & $\begin{array}{l}\text { n.a. } \\
\text { n.a. }\end{array}$ \\
\hline
\end{tabular}

*For PDL variables, an F-test also is given for the hypothesis that the parameters for each set (expenditures, money, oil variable) are jointly zero: $(a, b, c, d, e, f)=,(10,5,2.5,1,0.5,0.1)$ percent level. 
Results for the third approach to testing for structural change are summarized in Table VII. A comparison of forecast statistics is reported for equations estimated to $1980 \mathrm{Q} 2$ and for those estimated to $1982 \mathrm{Q} 4$. For the equation estimated to $1980 \mathrm{Q} 2$, forecast statistics are computed for two post-sample intervals: 1980Q3-87Q2 and 1983Q1-87Q2. The latter forecast is made starting eleven quarters after the end of the estimation interval and extending through the next twenty-eight quarters, or an eighteen-quarter forecast commencing eleven quarters after the end of the estimation interval. The forecast statistics of this interval are compared to the in-sample standard error and to those forecasts over eighteen quarters $1983 \mathrm{Q} 1-87 \mathrm{Q} 2$ for the equations estimated to 1982 Q4.

For the real GNP growth equations using M1A for the 1980Q2 equations, the RMSQE for 1983Q1-87Q2 is below the in-sample standard error and is superior to the RMSQE for the equations estimated to 1982Q4. This suggests that developments associated with financial deregulation during 1981-82 may have been largely transitory in their effect on the indicator properties of M1A. The same results hold for M1. M1A generally remains superior to M1 and M2 for the forecast criteria shown in Table VII.

The results for the inflation equations appear on the right-hand side of Table VII. For M1A, the 1983Q1-87Q2 RMSQE for the equation estimated to $1980 \mathrm{Q} 2$ is above the in-sample standard error and above the RMSQE for the equation estimated to $1982 \mathrm{Q} 4$. In the presence of the oil price, the RMSQE of the former is 2.28 versus 1.69 for the latter, or a difference of fifty-nine basis points. Differences of this magnitude are not especially small, but yet do not seem clearly indicative of significant structural change. ${ }^{13}$

In the case of M1, the equations estimated to $1980 \mathrm{Q} 2$ have forecast statistics over 1983Q1-87Q2 which are about as relatively inferior as those estimated to $1982 \mathrm{Q} 4$. Thus, the structural breakdown of M1 described in the first two approaches is confirmed again. For M2 over 1983Q1-87Q2, the RMSQE for the 1980Q2 equation is also above the in-sample standard error and the RMSQE for the 1982Q4 equation. As before, its error statistics are better than those of M1 but slightly worse than those of M1A. ${ }^{14}$

In summary, the three tests for structural change tend to indicate that since 1982 , and despite the occurrence of substantial financial deregulation, M1A has about the same indicator properties with respect to real growth and inflation as it had in previous years. The indicator properties of $\mathrm{M} 1$, and to a

13. Hafer [1984] compares MI and MIA in a version of the St. Louis equation. He finds a deterioration in the in-sample fit between 1979 Q4 and 1983Q2 for both M1 and M1A, but no deterioration for M1A when dummies are used for 1981Q1-Q3.

14. These results are consistent with those for nominal GNP as reported in Batten and Thornton [1983b]. 


\section{TABLE VI}

Out-of-Sample Forecast Statistics

1980Q2 Equations: Estimated over 1961Q1-80Q2

1982Q4 Equations: Estimated over 1961Q1-82Q4

\section{GNP Growth Equations}

\section{Inflation Equations*}

\begin{tabular}{lrrr}
\hline 1980Q2 equations (with oil shock) & & \\
$\bar{R}^{2}$ & .33 & .32 & .30 \\
SEE & 3.30 & 3.32 & 3.38 \\
RMSQE(80Q3-87Q2) & 2.78 & 3.26 & 3.62 \\
RMSQE(83Q1-87Q2) & 1.77 & 2.60 & 2.78 \\
MAE(80Q3-87Q2) & 2.15 & 2.54 & 2.66 \\
MAE(83Q1-87Q2) & 1.42 & 2.03 & 1.98 \\
ME(80Q3-87Q2) & -0.56 & 0.42 & -0.08 \\
ME(83Q1-87Q2) & -0.15 & 1.40 & 1.26
\end{tabular}

1980Q2 equations (with oil price)

$\begin{array}{lrrr}\bar{R}^{2} & .71 & .72 & .62 \\ \text { SEE } & 1.52 & 1.44 & 1.73 \\ \text { RMSQE(80Q3-87Q2) } & 2.45 & 4.74 & 2.29 \\ \text { RMSQE(83Q1-87Q2) } & 2.28 & 5.74 & 2.31 \\ \text { MAE(80Q3-87Q2) } & 2.02 & 4.17 & 2.02 \\ \text { MAE(83Q1-87Q2) } & 1.77 & 5.58 & 2.06 \\ \text { ME (80Q3-87Q2) } & 0.25 & -3.73 & -1.17 \\ \text { ME(83Q1-87Q2) } & -0.98 & -5.58 & -1.99\end{array}$

1982Q4 equations (with oil shock)

$\begin{array}{lrrr}\vec{R}^{2} & .37 & .34 & .29 \\ \text { SEE } & 3.32 & 3.40 & 3.54 \\ \text { RMSQE(83Q1-87Q2) } & 1.94 & 2.66 & 3.01 \\ \text { MAE(83Q1-87Q2) } & 1.53 & 2.17 & 2.12 \\ \text { ME(83Q1-87Q2) } & -0.45 & 0.88 & 0.88\end{array}$

1982 Q 4 equations (with oil price)

$\begin{array}{lrrr}\overrightarrow{\mathrm{R}} & .73 & .72 & .62 \\ \text { SEE } & 1.56 & 1.52 & 1.76 \\ \text { RMSQE(83Q1-87Q2) } & 1.69 & 5.56 & 1.71 \\ \text { MAE(83Q1-87Q2 } & 1.25 & 5.37 & 1.59 \\ \text { ME (83Q1-87Q2) } & -0.68 & -5.37 & -1.26\end{array}$

*Based on static forecasts. 
somewhat lesser extent $\mathrm{M} 2$, have in contrast undergone structural change which appears thus far to be permanent. ${ }^{15}$

\section{WHY THE M1-GNP RELATION BROKE DOWN}

The breakdown in the M1-GNP relation and the continued stability in the case of M1A appears related to the increased influence of OCDs on the behavior of M1 and to the possibility that OCDs may be relatively more savings- than transactions-like in character. Both aspects of the resulting change in M1 suggest that M1 may come to resemble the old M2. These considerations suggest in turn that, as in Figures 1 and 2, the trendless velocity of M1 since the early 1980 s may be permanent in nature, while the velocity of M1A may evolve in a manner similar to that of M1 prior to the 1980s. Looked at in another way, the relative stability of M1A may reflect the rising prominence of business activity in this aggregate.

Evidence of the first two aspects noted above are in Table VIII, which decomposes the quarterly mean and variance of growth rates for M1 and M2 over 1961Q1-79Q4 and 1981Q3-86Q4. The period 1980Q1-81Q2 is omitted to prevent distortions due to 1980 credit controls and to the impact effect of nationwide introduction of NOW accounts in 1981. The top half of Table VIII shows that prior to the 1980 s, about 90 percent of the mean and variance of M1 growth was accounted for my M1A. In the 1980s, however, OCDs accounted for about 57 percent of the mean growth of M1 and 44 percent of the variance of $\mathrm{M} 1$ growth. The lower half of Table VIII shows the analogous decomposition for M2. The relation between M2 and its non-M1 components show little change between the two periods. Thus, the contribution of M1 to the mean and variance of M2 growth also showed little change. But the relation between M1A and M2 has deteriorated in the 1980s, while that between OCDs and M2 has strengthened. This provides indirect evidence that OCDs have become more closely aligned in behavior with the nontransactions components in M2.

A third aspect to account for the relative stability of M1A is also presented in Table VIII. The mean and variance decomposition is given for the growth in two major components of ordinary demand deposits, nonfinancial business and individuals. The underlying series are available only over 1970Q2-86Q4 and are not seasonally adjusted (see Table VIII for source). As before, the shift in the composition of growth towards business deposits during the 1980s

15. Our results are consistent with those of Christiano [1986] who examines six measures of money to test if the relationship between money and the economy has changed in the 1980s. For difference-stationary models he finds that Spindt's [1985] weighted aggregate MQ did not evidence change, while M1, M2 and Barnett's monetary services aggregate MS1 (in Barnett [1980], Barnett and Spindt [1979] and Barnett et al [1984]) did show evidence of change. The MQ measure weights the components of M1 by their turnover. According to Batten and Thomton [1985], these weights since 1982 are about 18-22 percent for OCDs and 78-82 percent for the components of M1A. Thus MQ is dominated more by M1A than by OCDs. 


\section{TABLE VIII}

Growth Rate Decompositions* Using Annualized Quarterly Growth

\begin{tabular}{|c|c|c|c|c|c|c|}
\hline \multicolumn{7}{|c|}{ M1 Decomposition: } \\
\hline & $\begin{array}{c}\text { Mean Growth } \\
\text { M1 } \\
\end{array}$ & \multicolumn{2}{|c|}{ Contribution (\%) } & $\begin{array}{c}\text { Variance } \\
\text { MI } \\
\end{array}$ & \multicolumn{2}{|c|}{ Contribution (\%) } \\
\hline $79 \mathrm{Q} 2-79 \mathrm{Q} 4$ & 6.6 & 91.7 & 8.3 & 4.8 & 80.5 & 19.5 \\
\hline \multirow[t]{4}{*}{ 81Q3-86Q4 } & 9.6 & 42.2 & 57.0 & 18.8 & 65.2 & 43.8 \\
\hline & \multicolumn{6}{|c|}{ M2 Decomposition: } \\
\hline & Mean Growth & \multicolumn{2}{|c|}{ Contribution $(\%)$} & Variance & \multicolumn{2}{|c|}{ Contribution (\%) } \\
\hline & M1 & M1A OCD & (M2-M1) & $\mathrm{M2}$ & M1A & OCD (M2-M1) \\
\hline 61Q1-79Q4 & 8.4 & 20.0 & 79.1 & 9.2 & 14.1 & 85.2 \\
\hline $79 \mathrm{Q} 2-79 \mathrm{Q} 4$ & 9.8 & 18.3 & 80.2 & 9.6 & 12.1 & -0.9 \\
\hline 81Q3-86Q4 & 9.1 & 14.7 & 74.6 & 9.3 & 1.6 & 91.4 \\
\hline & Mean Growth & \multirow{2}{*}{\multicolumn{2}{|c|}{$\begin{array}{l}\text { Contribution (\%) } \\
\text { Business Individuals }\end{array}$}} & Variance & \multirow{2}{*}{\multicolumn{2}{|c|}{$\begin{array}{l}\text { Contribution (\%) } \\
\text { Business Individuals }\end{array}$}} \\
\hline & Total & & & Total & & \\
\hline $70 \mathrm{Q} 2-79 \mathrm{Q} 4$ & 7.4 & \multicolumn{2}{|c|}{40.6} & 247.1 & \multicolumn{2}{|r|}{21.9} \\
\hline 81Q3-86Q4 & 4.7 & \multicolumn{2}{|l|}{92.3} & 313.7 & \multicolumn{2}{|r|}{21.4} \\
\hline
\end{tabular}

*The variance decompositions are based on the following procedure. The growth of an aggregate is first decomposed into the share weighted growth rates of its components. Let this growth rate decomposition be written as $Y=x+w+z$. Then $\operatorname{var}(y)=\operatorname{covar}(y, x)+\operatorname{covar}(y, w)+\operatorname{covar}(y, z)$. This is the decomposition used in the table. For any given covariance, it can be further written as $\operatorname{covar}(y, x)=\operatorname{var}(x)+\operatorname{covar}(x, w)+\operatorname{covar}(x, z)$. Thus the contribution of $x$ to the variance of $y$ is its covariation with $y$, which in turn reflects the variance of $x$ as well as its covariance with other components of $y$.

**Total is sum of individuals and nonfinancial business, and series are not seasonally adjusted (NSA). Data provided unofficially by staff of Federal Reserve Board of Governors. 
reflects the rising importance of OCDs for individuals. In contrast, however, the variance decomposition has been quite stable between the two periods, with business activity accounting for almost 80 percent of total variance. Thus, the evidence on business versus individual behavior is somewhat mixed.

A more direct explanation of the breakdown between M1 and GNP is available by looking at velocity. Recently, Rasche [1987] has shown that a significant negative shift occurred in M1 velocity starting in late 1981 or early 1982, even when taking into account the declines in interest rates and inflation, and after adjusting the M1 data for the nationwide introduction of NOWs in 1981Q1. In a comment on Rasche's results, Mascaro [1987] used a simple model of M1A and OCD demands and produced preliminary evidence which suggests that interest rate deregulation played a major role in the M1 velocity shift. With deregulation at the start of 1981 , OCDs became available nationwide and expanded rapidly. Since these deposits combine elements of savings and transactions and are included in M1, their expansion altered the behavior of M1 money demand and velocity and changed the M1-GNP relationship.

Following the approach taken by Mascaro [1987], an estimate can be made of the effect of deregulation on M1 velocity by focusing on the M1A and OCD components of real M1 money demand as shown in growth rate terms in equations (1) and (2).

$$
\begin{gathered}
D \ln (M 1 A)=-a_{0}+a_{1}(L) D \ln (y)-a_{2}(L) D \ln a(R)+a_{3}(L) D \ln (P)+u \\
D \ln (O C D)=-b_{0}+b_{1}(L) D \ln (y)-b_{2}(L) D \ln (R-R D)+b_{3}(L) D \ln (P)+z
\end{gathered}
$$

where

$$
\begin{gathered}
D x=x(t)-x(t-1), \ln (x)=\text { natural logarithm of } x, L^{j} x(t)=x(y-j), \\
k(L)=k_{0}+k_{1} L+K_{2} L^{2} .
\end{gathered}
$$

Real demands are functions of real income $(y)$, opportunity costs and prices $(P)$. The opportunity cost of real M1A is the short-term market rate $(R)$ (measured by the three-month Treasury Bill rate) while that for OCDs is given by the market rate less the rate on OCDs $(R D)$. The presence of prices in real demands reflects the lack of instantaneous adjustment of prices to changes in money supply. Presumably, the coefficients of $a_{3}(L), b_{3}(L)$ should each sum to zero if money ultimately has a one-to-one effect on the price level. The constant terms $\left(-a_{0},-b_{0}\right)$ represent trend declines in real money demands, given real income and interest rates, as a result of improvements in the payments mechanism. 
Using the two real money demands, the growth of M1 velocity is given by equation (3) (where $w=M 1 A / M 1$ ):

$$
\begin{aligned}
\operatorname{Dln}(V M 1) & =b_{0}+\left(a_{0}-b_{0}\right) w+\left[1-w a_{1}(L)-(1-w) b_{1}(L)\right] \operatorname{Dln}(y) \\
& +\left[w a_{2}(L)+(1-w) b_{2}(L)\right] \operatorname{Dln}(R) \\
& -(1-w) b_{2}(L) \mathrm{D}(R D / R) \\
& -\left[w a_{3}(L)+(1-w) b_{3}(L) \operatorname{Dln}(P) .\right.
\end{aligned}
$$

Two aspects of equation (3) help to explain the lack of a positive trend of M1 velocity since the early 1980 s. First, as OCDs increase in importance, the term $\left(a_{0}-b_{0}\right)$ will decline as $w$ falls if $a_{0}>b_{0}$. This latter condition will hold if there is greater incentive to economize on noninterest balances in M1A than on interest-earning balances in OCDs. Second, the spread $\mathrm{D}(R D / R)$ will begin to exert a negative effect on M1 velocity as OCDs increase relative to M1 (i.e., as $w$ declines from unity). The spread term would have had little effect prior to the 1980s because in that period $w$ was approximately unity. When $w$ is approximately unity, the velocity of Ml would be indistinguishable from that of M1A and the trend of M1 velocity would be based largely on the M1A measure of velocity.

To estimate equation (3), it is assumed that $a_{j}(L)=b_{j}(L), j=1,2,3$, since otherwise a problem with multicollinearity arises due to the presence of such terms as $D \ln (y)$ and $w D \ln (y)$. As passage of time allows more realizations of data, this assumption could be relaxed. Following Rasche [1987], it is also assumed that $a_{1}(L)$ has three terms which sum to unity, and that the second and third terms are equal. Together, these restrictions imply that a measure of transitory income is the relevant underlying income variable in equation (3). Rasche's assumption that the interest rate coefficients, $a_{2}(L)$, have a uniform distribution is also adopted, although it is not critical for the results. (These assumptions on $D \ln (y)$ and $D \ln (R)$ were tested by Rasche.) Instead of the price variable of equation (3), Rasche uses as a measure of unanticipated inflation the residuals from an ARIMA $(0,1,1)$ model. For a moving average parameter of 0.5 , this is close to using the current inflation rate less the average of its two lagged values. ${ }^{16}$ This is analogous to the construction used to define transitory income. It also implies that the coefficients of $a_{3}(L)$ sum to zero and that the two lagged coefficients are equal. This form is used for unanticipated inflation. Finally, for the interest-rate spread in equation (3),

16. The difference between unanticipated inflation as defined here and that from the residuals of ARIMA $(0,1,1)$ process is equal to $-h^{2} a(t-2)$, where $a(t)$ is the ARIMA residual and $h$ is the moving average parameter. 
$\mathrm{D}(R D / R)$, this variable is set to zero until the start of 1979 , when NOW accounts were made available in New York as well as New England.

Table IX presents an estimate of equation (3) over 1961Q1-82Q4 and a summary of forecast statistics over 1983Q1-87Q2. The predicted and actual growth of M1 velocity are shown in Figure 4. Data for rates on NOW and Super NOW accounts are from various issues of the Federal Reserve Bulletin and Federal Reserve Statistical Release H.6 (508). Quarterly data are derived as averages of monthly data. Two aspects of the empirical results are interesting. First, two of the three spread terms, $D(R D / R)$, have the expected negative sign. While only the spread term lagged one quarter is significant, a joint test on the current and lagged terms has an $F(3,80)$-statistic of 10.08 which is significant beyond the 99 percent confidence level. Second, the coefficient on $w$ is positive and significant at the 95 percent level. Its value, together with that for the constant of the regression, implies a value for $a_{0}$ of 2.84 , which is near the historical trend growth of M1 velocity. This in turn suggests that the trend velocity of M1A, as implied by the velocity equivalent of equation (2), has not changed. In a regression not reported, omission of the constant leads to an estimate of $a_{0}=2.74(t=8.54)$ with no significant change in other coefficients. Since this implies $b_{0}=0$, it suggests that OCDs are more savings-than transactions-like in their behavior.

The lower part of Table IX indicates that over the entire eighteen quarters of out-of-sample forecasting, there is mixed evidence of a breakdown in the equation. While over 1983Q1-87Q2 the RMSQE is higher than the in-sample SEE (4.14 vs. 2.81 ), the mean error does not indicate any significant forecast bias. The largest source of forecast error occurs in 1987, however, seventeen and eighteen quarters beyond the estimation interval, as can be seen in Figure 4. The RMSQE falls after 1984, with the smallest occurring in 1986. This is consistent with evidence presented earlier which suggested that transitory (as opposed to permanent) changes were taking place as a result of deregulation.

To summarize, this simple model suggests that the changed behavior of $\mathrm{M} 1$ velocity is traceable to the OCD component of M1 money demand. The evidence presented here is also consistent with that given elsewhere in the paper regarding the relative stability of the M1A-GNP relation.

\section{M1A VERSUS M2: IS THERE A CHOICE?}

While these results indicate the present inferiority of $\mathrm{M} 1$ as a monetary indicator because of structural changes since the early 1980s, they suggest somewhat mixed conclusions concerning the indicator properties of M1A versus M2. On the surface, the evidence from the implied nominal GNP predictions tend to favor M2. But the results of the disaggregation into real growth and inflation components suggest a less clear-cut choice. Short-run fluctuations in real growth are far more closely described by the pattern of 


\section{TABLE IX}

Growth in M1 Velocity

Equation (3): Ordinary least squares, 1961Q1-82Q4; predicted, 1983Q1-87Q2

(Absolute t-statistics in parentheses)

$$
\begin{aligned}
\operatorname{Dln}(V M 1)= & -6.557+9.397 * w+0.48 \text { (transitory income growth) } \\
& (0.949)(1.337)^{\mathrm{a}} \quad(6.396)^{\mathrm{a}} \\
+ & 0.49 \text { (unanticipated inflation) } \\
& (2.560)^{\mathrm{a}} \\
+ & 0.015[\mathrm{D} \ln (R)+\mathrm{D} \ln (R)-1+\mathrm{D} \ln (R)-2] \\
& (3.566)^{\mathrm{a}} \mathrm{a} \\
- & 0.061(1-w) \mathrm{D}(R D / R)-0.981(1-w) \mathrm{D}(R D / R)-1+0.039(1-w) \mathrm{D}(R D / R)-2 \\
& (0.01) \quad(5.391)^{\mathrm{a}} \quad(0.176)
\end{aligned}
$$

$\overrightarrow{\mathrm{R}}^{2}=.61 ; \mathrm{F}(7,80)=20.41 ; \mathrm{D} . \mathrm{W} .=1.75, \mathrm{SEE}=2.81$, number of observations $=88$.

$\begin{array}{lrr} & \mathbf{5 \%} & \mathbf{1 \%} \\ \text { D.W.1 } & 1.34 & 1.40 \\ \text { D.W.u } & 1.78 & 1.64\end{array}$

$\begin{array}{lcccccc}\text { Forecast Statistics } & \begin{array}{c}1983 Q 1- \\ 87 Q 2\end{array} & \begin{array}{c}1983 Q 1- \\ 86 Q 4\end{array} & 1983 & 1984 & 1985 & 1986 \\ \text { RMSQE } & 4.14 & 3.49 & 3.80 & 3.94 & 3.10 & 3.03 \\ \text { MAE } & 3.10 & 2.55 & 2.88 & 2.50 & 2.23 & 2.60 \\ \text { ME } & -0.83 & 0.01 & -0.33 & 1.74 & 1.22 & -2.60\end{array}$

Percentage of error due to random variation $=97.7,1983-86$.

Note: $R=$ three-month Treasury bill rate, $w=M 1 A / M 1 ; R D=$ share-weighted average of rates on NOWs and Super NOWs 1983-85, rate on NOWs before 1983, rate on NOWs in 1986.

aSignificant at 5 percent level (two-tailed test). 
FIGURE 4

M1 Velocity: Actual vs. Predicted

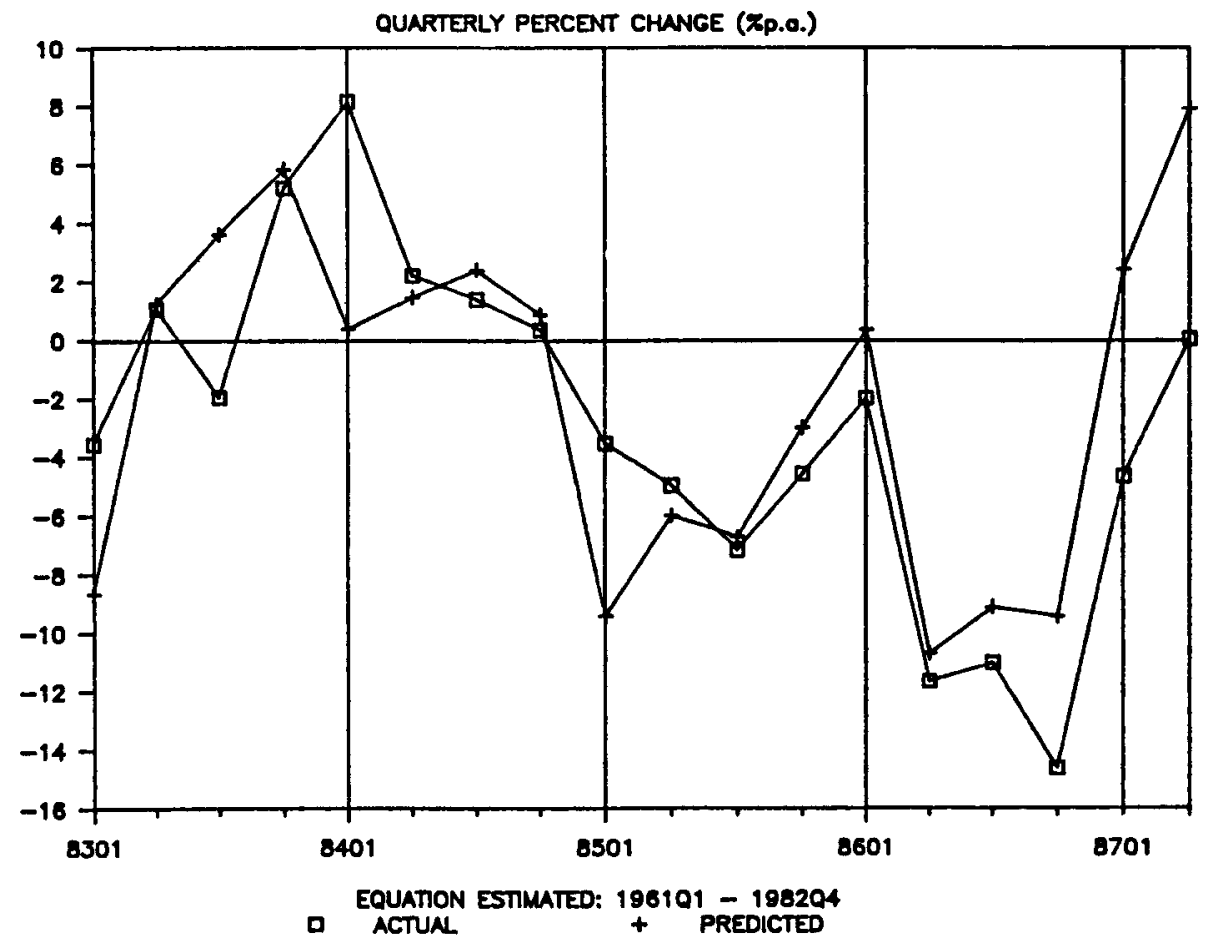


M1A growth than by that of M2. In particular, for the equations estimated to $1982 \mathrm{Q} 4$, the correlation of actual with post-sample (1983Q1-87Q2) predicted real GNP growth is .71 using M1A, .35 using M1, but only .17 using M2. This suggests that when policymakers pursue short-run discretionary policy, M1A provides better information than M2 on the short-run consequences for real growth of such policy. In contrast, actual inflation, postsample, is more highly correlated with the predictions using M2 (.36) than with those using M1A (-.22). This may reflect the lower variance-to-mean ratio for $M 2$ versus $M 1 A$, and suggests that when only long-run price level stability or nominal GNP growth is the primary focus of policy, then M2 is a relatively good indicator of the long-run inflation consequences of discretionary policy. In effect, the relatively low noise-to-signal ratio which may make M2 a good indicator of the long-run inflation consequences of discretionary monetary policy simultaneously impairs its usefulness as an indicator of the short-run real growth consequences of policy when M2 is the aggregate target.

There is another feature which enters into the choice of M1A versus M2. As a result of interest rate deregulation, there are assets in M2 (but not in M1A) which offer a return that is market-related. This is apt to make M2 less interest-sensitive than M1A, so that when there are changes in money supply, movements in interest rates will exert a greater effect on the quantity demanded of M1A than of M2. This may explain why M1A has overpredicted inflation since late 1986, a time when money growth accelerated while interest rates and M1A velocity declined. If monetary aggregates are being targeted at a time when monetary policy is directed toward interest rates, the more interest-sensitive aggregate will require a wider target range, or the target may well be missed when there are significant changes in interest rate targets. Thus, the choice between M1A and M2 may also hinge on the extent to which monetary policy is oriented towards targeting interest rates versus targeting money growth.

\section{REFERENCES}

Andersen, Leonall C. and Jerry L. Jordan. "Monetary and Fiscal Actions: A Test of Their Relative Importance in Economic Stabilization." Federal Reserve Bank of St. Louis Review, November 1968, 11-23.

Bamett, William A. "Economic Monetary Aggregates: An Application of Index Numbers and Aggregation Theory." Journal of Econometrics, September 1980, 11-48.

Bamett, William A. and Paul A. Sprindt. "The Velocity Behavior and Information Content of Divisia Monetary Aggregates." Economic Letters, 4, 1979, 51-57.

Barnett, William A., Edward K. Offenbacher and Paul A Spindt. "The New Divisia Monetary Aggregates." Journal of Political Economy, December 1984, 1049-85.

Barro, Robert J. "Unanticipated Money, Output, and the Price Level in the United States." Journal of Political Economy, August 1978, 549-80.

. Money, Expectations and Business Cycles. New York: Academic Press, 1981. 
Barro, Robert J. and Mark Rush. "Unanticipated Money and Economic Activity," in Rational Expectations and Economic Policy, edited by Stanley Fischer. Chicago: University of Chicago Press, 1980.

Batten, Dallas and Daniel L. Thornton. "Polynomial Distributed Lags and the Estimation of the St. Louis Equation." Federal Reserve Bank of St. Louis Review, April 1983a, 13-25.

"M1 or M2: Which Is the Better Monetary Target?" Federal Reserve Bank of St. Louis Review, June/July 1983b, 36-42.

"Are Weighted Monetary Aggregates Better than Simple-Sum M1?" Federal Reserve Bank of St. Louis Review, June/July 1985, 29-40.

"The Monetary-Fiscal Policy Debate and the Andersen-Jordan Equation." Federal Reserve Bank of St. Louis Review, October 1986, 9-17.

Blue Chip Economic Indicators. Capitol Publishing Inc., Alexandria, Va., 1982-1987.

Carlson, Keith M. "The Lag from Money to Prices." Federal Reserve Bank of St. Louis Review, October 1980, 3-10.

Carr, Jack and Michael R. Darby. "The Role of Money Supply Shocks in the Short-Run Demand for Money." Journal of Monetary Economics, September 1981, 183-99.

Chow, Gregory C. "Tests of Equality between Sets of Coefficients in Two Linear Regressions." Econometrica, July 1960, 591-605.

Christiano, Lawrence J. "Money and the U.S. Economy in the 1980s: A Break from the Past?" Federal Reserve Bank of Minneapolis Quarterly Review, Summer 1986, 2-13.

Darby, Michael R. "The Allocation of Transitory Income among Consumers' Assets." American Economic Review, December 1972, 928-41.

"The Financial and Tax Effects of Monetary Policy on Interest Rates." Economic Inquiry, June 1975, 266-76.

"The Price of Oil and World Inflation and Recession." American Economic Review, September 1982, 738-51.

Darby, Michael R., Angelo R. Mascaro and Michael L. Marlow. "The Empirical Reliability of Monetary Aggregates as Indicators: 1983-1987." Research Paper No. 8701, U.S. Department of Treasury, Washington, D.C. 1987.

Federal Reserve Board. "Monetary Policy Report to Congress," Federal Reserve Bulletin, March 1981, 195-208.

. Federal Reserve Bulletin, 1979-1987.

Statistical Release H.6, 1979-1987.

Fisher, Franklin M. "Tests of Equality between Sets of Coefficients in Two Linear Regressions: An Expository Note." Econometrica, March 1970, 361-66.

Friedman, Milton. "What Could Reasonably Have Been Expected from Monetarism: The United States." Paper for the Mont Pelerin Society, August 29, 1985, Vancouver, Canada.

"The Needle Got Stuck." Newsweek, 25, July 1985, 66.

Friedman, Milton and Anna Schwartz. Monetary Statistics of the United States. New York: Columbia University Press for National Bureau of Economic Research, 1970.

Monetary Trends in the United States and the United Kingdom. Chicago: University of Chicago Press, 1982.

Hafer, R. W. "The Money-GNP Link: Assessing Alternative Transaction Measures." Federal Reserve Bank of St. Louis Review, March 1984, 19-27.

Jordan, Jerry L. "The Andersen-Jordan Approach after Nearly 20 Years." Federal Reserve Bank of St. Louis Review, October 1986, 5-8.

Judd, John P. "The Recent Decline in Velocity: Instability in Money Demand or Inflation?" Federal Reserve Bank of San Francisco Economic Review, Spring 1983, 12-19.

Keeley, M. C., and G. C. Zimmerman. "Interest Checking and M1." Federal Reserve Bank of San Francisco Weekly Letter, November 1986, 1-3. 
Mascaro, Angelo R. "Comments on Paper by Rasche." Carnegie-Rochester Conference Series in Public Policy. Amsterdam: North-Holland, Autumn 1987, 89-102.

Mayer, Wolfgang. "Short-Run and Long-Run Equilibrium for a Small Open Economy." Journal of Political Economy, September/October 1984, 955-68.

Mork, Knut A. "The Boom That Wasn't: Evidence from 1986-87 on the Macroeconomic Effects of Oil Price Fluctuations," unpublished manuscript, Vanderbilt University, 1987.

Oilgram News, McGraw Hill, 1960-1987.

Paulus, John D. "Monetarism: If It Ain't Broke Don't Fix It." Morgan Stanley Economic Perspectives, 1986, 1-9.

Petroleum Intelligence Weekly, Petroleum Finance O., 1960-1987.

Platt's Oil Price Report, McGraw Hill, 1960-1987.

Probyn, Christopher and Mark Booth. "Does M1 Matter Anymore?" Data Resources U.S. Long-Term Review, Summer 1986, 30-35.

Rasche, Robert H. "M1 Velocity and Money Demand Functions: Do Stable Relationships Exist?" Carnegie Rochester Conference Series in Public Policy. Amsterdam: North Holland, Autumn 1987, 9-88.

Rasche, Robert H. and John Tatom. "Energy Resources and Potential GNP." Federal Reserve Bank of St. Louis Review, June 1977, 10-24.

Sargent, Thomas J. and Neil Wallace. "Rational Expectations and the Theory of Economic Policy." Studies in Monetary Economics, Federal Reserve Bank of Minneapolis, 1975, 1-9.

Spindt, Paul A. "Money Is What Money Does: Monetary Aggregation and the Equation of Exchange." Journal of Political Economy, February 1985, 175-204. 